\title{
Oxidation behavior and microstructure evolution of alumina-forming austenitic $\&$ high entropy alloys in steam environment at $1200^{\circ} \mathrm{C}$
}

Hao Shi ${ }^{a}$, Chongchong Tang ${ }^{b}$, Adrian Jianu, ${ }^{a, *}$, Renate Fetzer ${ }^{a}$, Alfons Weisenburger ${ }^{a}$, Martin Steinbrueck ${ }^{b}$, Mirco Grosse ${ }^{b}$, Robert Stieglitz ${ }^{c}$, Georg Müller ${ }^{\mathrm{a}}$

a Institute for Pulsed Power and Microwave Technology, Karlsruhe Institute of Technology (KIT), Hermann- vonHelmholtz-Platz 1, 76344 Eggenstein-Leopoldshafen, Germany

${ }^{b}$ Institute for Applied Materials (IAM), Karlsruhe Institute of Technology (KIT), Hermann- von-Helmholtz-Platz 1, 76344 Eggenstein-Leopoldshafen, Germany

' Institute for Neutron for Neutron Physics and Reactor Technology, Karlsruhe Institute of Technology (KIT), Hermannvon-Helmholtz-Platz 1, 76344, Eggenstein-Leopoldshafen, Germany

* Corresponding author. E-mail address: adrian.jianu@kit.edu (A. Jianu).

Keywords: Alumina-forming austenitic alloy; High entropy alloy; Fe-Cr-Al-Ni alloy; Steam oxidation; Alumina scale formation.

\begin{abstract}
Oxidation tests of alumina-forming austenitic (AFA) alloys and high entropy alloys (HEA) have been performed in steam at $120{ }^{\circ} \mathrm{C}$. AFA alloys with composition formula Fe-3Al-16Cr-(19-21)Ni (wt.\%) and HEA with formula $\mathrm{Al}_{(7.9-8.9)} \mathrm{Cr}_{(21.4-23.2)} \mathrm{Ni}_{(34.3-35)} \mathrm{Fe}_{\text {bal }}$ (at.\%) show low oxidation rate due to the formation of $\alpha$ $\mathrm{Al}_{2} \mathrm{O}_{3}$ scale. By adding yttrium to AFA or niobium to $\mathrm{HEA}$, the samples show no evidence of scale exfoliation. $\mathrm{HEA}$ with titanium addition forms a thick oxide layer based on $\mathrm{TiO}_{2}, \mathrm{Cr}_{2} \mathrm{O}_{3}$ and internal $\mathrm{Al}$ oxidation. The growth of oxide scale is discussed based on the oxygen partial pressure of metal oxides and dissociation oxygen pressure of the steam.
\end{abstract}

\section{Introduction}

The worldwide increasing demand on energy supply requires to improve the energy production/conversion efficiency, for instance developing advanced ultra-supercritical coal power plants (operation temperature $>750{ }^{\circ} \mathrm{C}$ ), and to search for clean and renewable energy solutions like hydrogen production via steam reforming of methane $\left(\sim 850{ }^{\circ} \mathrm{C}\right)$, thermo-chemical water-splitting, and using of biomass-derived syngas [1-3]. For these applications, steam can be employed as the agent in the gasification and pyrolysis system [3-4]. However, degradation of structural materials (e.g. ferritic and austenitic steel, Ni-based alloys) in steam/water vapor environments at above $800{ }^{\circ} \mathrm{C}$, in terms of corrosion and mechanical failure, may significantly shorten the lifetime of the system [5-8]. Another case involved is the steam oxidation induced degradation of cladding tubes in light water reactors (LWRs). During the last few decades, Zr-based alloys have been commercialized as fuel cladding structures due to their excellent high temperature mechanical properties, irradiation and corrosion resistance [9-11]. However, in case of accident scenarios, zirconium alloy undergoes rapid exothermic reaction with high temperature steam, accompanied by hydrogen release, strongly affecting severe accident progression and release of radioactive fission products $[7,12,13]$. Therefore, new accident tolerant nuclear fuel (ATF) has been proposed as a consequence of the Fukushima Daiichi accidents [14-16]. 
Conventional structural materials (e.g T22, 9Cr-1Mo, E1250, 316L, Inconel 625, Zr alloy etc.) rely on magnetite, chromia or zirconia rich scale for oxidation protection in steam environment at temperature below $800^{\circ} \mathrm{C}[5-8,10]$. However, the fast growth of the Fe-, $\mathrm{Cr}$-rich oxide scale leads to thickening of the oxide layer and reduced heat transfer [5-6, 17]. Ehlers et al. [18] suggest that volatile hydroxides like $\mathrm{Fe}(\mathrm{OH})_{2}$ form on $9 \% \mathrm{Cr}$ steels at low oxygen partial pressure in the inner layers of the scale. These volatile hydroxides are then converted to hematite or magnetite in the outer layer, thus contributing to the observed high oxidation rate. In contrast, alumina scale shows significantly lower growth rate even above $800{ }^{\circ} \mathrm{C}$ and high thermodynamic stability in aggressive environments (e.g. water vapor/steam, molten $\mathrm{Pb}$, supercritical $\mathrm{CO}_{2}$ conditions, molten chloride salts, metal dusting conditions) [19-24].

Steam oxidation tests of $\mathrm{Fe}-, \mathrm{Ni}$ - based alloys above $800^{\circ} \mathrm{C}$ available in literature are mainly focused on alumina-forming Fe-Cr-Al alloys [15, 17, 20, 25-27]. In the temperature range of $800-1000{ }^{\circ} \mathrm{C}$, the oxide scale formed on Fe-21Cr-5Al-3Mo (Kanthal APMT) and Fe-12Cr-6Al-2Mo (C26M) consists of an outer layer of $\mathrm{Al}-, \mathrm{Cr}-$, Fe-rich oxides, and an inner Al-rich oxide layer [26]. When the temperature is beyond $1000{ }^{\circ} \mathrm{C}$, only an alumina layer is observed [20, 26, 27]. Moreover, the adherence of $\alpha-\mathrm{Al}_{2} \mathrm{O}_{3}$ scale formed on Fe$\mathrm{Cr}$-Al alloys at $1200{ }^{\circ} \mathrm{C}$ is significantly improved by adding $0.3 \mathrm{wt}$.\% yttrium [20]. However, Fe-Cr-Al alloys suffer from embrittlement due to Fe-Cr ferrite phase separating into Fe-rich ferrite $(\alpha)$ and $\mathrm{Cr}$-rich ferrite $\left(\alpha^{\prime}\right)$ phases at around $400{ }^{\circ} \mathrm{C}$, which challenges their high temperature application [28-31]. To avoid this issue and to improve the high temperature mechanical properties of alumina-forming alloys, Kim et al. [32] has designed the alumina-forming duplex stainless steels (ADSS) and investigated their oxidation behavior in steam. After $8 \mathrm{~h}$ exposure to steam at $1200^{\circ} \mathrm{C}$, alloy ADSS\#B51 (Fe-19Ni-16Cr-6Al-base, wt.\%) has gained less mass than $310 \mathrm{~S}$ (Fe-19.1Ni-24.7Cr-0.87Mn-base, wt.\%) but more than APM (Fe-21.9Cr$5.8 \mathrm{Al}$ base, wt.\%). Cross section analysis of exposed ADSS alloys indicates the formation of oxide scale mainly consisting of $\mathrm{Fe}-\mathrm{Ni}-\mathrm{Ni}$-rich spinel outer layer $(10-20 \mu \mathrm{m})$ and $\alpha-\mathrm{Al}_{2} \mathrm{O}_{3}$ inner layer $(2-3 \mu \mathrm{m})$.

A representative alumina forming austenitic (AFA) alloy family $\mathrm{Fe}-(2.5-4) \mathrm{Al}-(12-15) \mathrm{Cr}-(12-$ 30) $\mathrm{Ni}-(0.6-3) \mathrm{Nb}$ (wt.\%), which shows excellent oxidation resistance by forming a protective alumina rich scale, has been developed [19, 33-35]. A minimum amount of $2.5 \mathrm{wt}$.\% Al is required to form an external alumina scale [19]. The amount of $\mathrm{Ni}$ added has to balance with $\mathrm{Al}$ and $\mathrm{Cr}$ contents in order to maintain the austenitic matrix (face centered cubic-FCC structure). Minor addition of reactive elements like $\mathrm{Y}, \mathrm{Hf}$ and $\mathrm{Zr}$ can improve the adherence of $\mathrm{Al}_{2} \mathrm{O}_{3}$ and $\mathrm{Cr}_{2} \mathrm{O}_{3}$ scale $[34,36]$. Moreover, by introducing thermodynamically stable and strengthening phases, namely $\mathrm{Fe}_{2} \mathrm{Nb}$ (Laves), $\beta-\mathrm{NiAl}$ (B2), $\gamma^{\prime}-\mathrm{Ni}_{3}(\mathrm{Al}, \mathrm{Ti}$ ) and $\mathrm{MC}$ $(\mathrm{M}=\mathrm{Cr}, \mathrm{Nb}), \mathrm{AFA}$ alloys have shown comparable or even better high temperature mechanical properties (e.g. creep strength) when compared with commercial austenitic and ferritic steels [19, 35-38]. Based on the $\mathrm{Ni}$ content and on the targeted alumina formation temperature range, the AFA steels are classified into three categories: (i) high $\mathrm{Ni}$-content (30-35wt\%), with relatively high strength, for applications in the temperature range $750-850^{\circ} \mathrm{C}$, (ii) standard $\mathrm{Ni}$-content $(20--5 \mathrm{wt} \%)$ for applications in the temperature range $750-950^{\circ} \mathrm{C}$ and (iii) low $\mathrm{Ni}$-content $(12-15 \mathrm{wt} \%)$, for the temperature range $650-700^{\circ} \mathrm{C}[77]$. 
High entropy alloys (HEA) were originally defined as the alloys containing five or more principle elements, each with a composition in the range of 5-35 at.\%, with high entropy (entropy of mixing $>1.61 R$, R: gas constant) [39]. Recently, Yang and Zhang et al. [40] redefined the concept by considering both the contributions from entropy of mixing $\left(\Delta S_{\text {mix }}\right)$ and enthalpy of mixing $\left(\Delta H_{\text {mix }}\right)$. Alloys with the parameter $\Omega$ larger than 1 can be considered as $\operatorname{HEA}\left(\Omega=\left(\Sigma c_{i} T_{m, i}\right) \Delta S_{\text {mix }} /\left|\Delta H_{\text {mix }}\right|, T_{m, i}\right.$ is the melting temperature of element $\mathrm{i}, c_{i}$ is the concentration of element i) [40]. This definition expands the range of searching for HEA alloys with three or four principle elements. Recently, HEAs have received numerous attentions for high temperature applications due to their excellent mechanical properties such as high strength, hardness and ductility, superior corrosion resistance, and structural stability [39-43]. HEA alloys with addition of Al and/or $\mathrm{Cr}$ are expected to withstand temperatures above $1000{ }^{\circ} \mathrm{C}$ by forming protective $\mathrm{Al}_{2} \mathrm{O}_{3}$ and/or $\mathrm{Cr}_{2} \mathrm{O}_{3}$ scale [44-47].

Recently, AFA model alloys with the backbone of Fe-Al-Cr-Ni have been designed based on equilibrium phase calculations [48]. Alumina-forming HEA model alloys $\mathrm{Fe}-\mathrm{Al}-\mathrm{Cr}-\mathrm{Ni}$-( $\mathrm{Nb}$ or Ti) have been designed by employing three parameters, namely, enthalpy of mixing $\left(\Delta H_{\text {mix }}\right)$, atomic radius difference $(\delta r)$ and valance electron concentration (VEC) [49]. By limiting the range of these parameters, for instance -15 $\mathrm{kJ} / \mathrm{mol}<\Delta H_{\text {mix }}<5 \mathrm{~kJ} / \mathrm{mol}$ and $\delta r<6.6 \%$, the solid solution can be predicted in a known HEA family which is based on the $3 d$ transition metal family [49-50]. Furthermore, an alloy with single FCC solid solution is expected when VEC $>7.8$ while FCC solid solution and intermetallic compounds can form when $7.5<V E C$ $<7.8$ [51-52]. Both types of model alloys, AFA and HEA, were tested in steam atmosphere at $1200^{\circ} \mathrm{C}$. This is not the envisaged operating temperature for any of the energy-related systems mentioned above. However, higher temperatures can be reached when accidents happen (e.g. the loss of coolant [15, 53]). Under such circumstances, for safety reasons, the materials should have structural integrity - without breaking, deforming excessively or totally oxidizing - for a defined period. Then a systematical microstructure characterization has been performed after oxidation test. The results obtained in this study are foreseen to help broaden the applications of alumina-forming austenite and high entropy alloys in steam-containing harsh environments.

\section{Materials and Experimental methods}

All as-cast samples were prepared from highly pure alloying elements (purity> 99.99\%) by vacuum arc-melting in argon atmosphere. The ingots were flipped over and melted at least 5 times in order to homogenize the chemical compositions. The as cast AFA samples were further annealed at $1250{ }^{\circ} \mathrm{C}$ for 2 hours in Ar atmosphere, followed by water quenching. Table 1 shows the nominal compositions and the chemical compositions of AFA model alloys measured by energy dispersive X-ray spectroscopy (EDS). Table 2 shows the nominal compositions and the measured compositions of HEA model alloys. HEA-1 has

formed single phase, while HEA-2 forms a matrix with precipitates, and HEA-3 and HEA-4 show a dendrite morphology. 
Table 1 Chemical compositions of annealed AFA model alloys measured by EDS (wt.\%)

\begin{tabular}{lllllll}
\hline Code & Nominal composition (wt.\%) & Al & $\mathrm{Cr}$ & $\mathrm{Ni}$ & $\mathrm{Y}$ & $\mathrm{Fe}$ \\
\hline AFA-1 & Fe-7Al-15Cr-27Ni & 6.8 & 14.4 & 26.7 & --- & Bal. \\
AFA-2 & Fe-3Al-16Cr-19Ni-0.5Y & 3.4 & 16.2 & 19.3 & 0.3 & Bal. \\
AFA-3 & Fe-3Al-16Cr-21Ni-0.5Y & 3.3 & 16.3 & 21.2 & 0.2 & Bal. \\
\hline
\end{tabular}

Table 2 Chemical compositions of as cast HEA model alloys measured by EDS (at.\%)

\begin{tabular}{|c|c|c|c|c|c|c|c|c|}
\hline Alloy & Nominal composition (at.\%) & Morphology & Al & $\mathrm{Cr}$ & $\mathrm{Fe}$ & $\mathrm{Ni}$ & $\mathrm{Nb}$ & $\mathrm{Ti}$ \\
\hline HEA-1 & $\mathrm{Al}_{7.9} \mathrm{Cr}_{23.2} \mathrm{Fe}_{34.1} \mathrm{Ni}_{34.8}$ & $\mathrm{SPh}$ & 7.9 & 23.7 & 34.4 & 34.0 & --- & --- \\
\hline HEA-2 & $\mathrm{Al}_{8.9} \mathrm{Cr}_{23.1} \mathrm{Fe}_{33.7} \mathrm{Ni}_{34.3}$ & $\begin{array}{l}M \\
P\end{array}$ & $\begin{array}{l}9.7 \\
11.8\end{array}$ & $\begin{array}{l}23.8 \\
23.7\end{array}$ & $\begin{array}{l}33.3 \\
29.3\end{array}$ & $\begin{array}{l}33.1 \\
35.2\end{array}$ & & \\
\hline HEA-3 & $\mathrm{Al}_{8.2} \mathrm{Cr}_{21.4} \mathrm{Fe}_{30.3} \mathrm{Ni}_{35} \mathrm{Nb}_{5.1}$ & $\begin{array}{l}\mathrm{D} \\
\mathrm{ID}\end{array}$ & $\begin{array}{l}7.1 \\
6.2\end{array}$ & $\begin{array}{l}23.3 \\
19.6\end{array}$ & $\begin{array}{l}34.4 \\
26.7\end{array}$ & $\begin{array}{l}34.1 \\
30.8\end{array}$ & $\begin{array}{l}1.2 \\
16.8\end{array}$ & \\
\hline HEA-4 & $\mathrm{Al}_{7.9} \mathrm{Cr}_{22} \mathrm{Fe}_{31.9} \mathrm{Ni}_{33.2} \mathrm{Ti}_{5}$ & $\begin{array}{l}\mathrm{D} \\
\mathrm{ID}\end{array}$ & $\begin{array}{l}6.5 \\
14.0\end{array}$ & $\begin{array}{l}23.9 \\
15.2\end{array}$ & $\begin{array}{l}35.7 \\
23.5\end{array}$ & $\begin{array}{l}31.1 \\
38.9\end{array}$ & & $\begin{array}{l}2.7 \\
8.4\end{array}$ \\
\hline
\end{tabular}

SPh: single phase; M: matrix; P: precipitates; D: dendrite; ID: inter-dendrite

The steam oxidation experiments were conducted using a horizontal tube furnace, the so-called BOX rig [54], under atmospheric pressure. The tube furnace consists of an alumina reaction tube (inner diameter: $32 \mathrm{~mm}$, length: $600 \mathrm{~mm}$ ) and molybdenum heaters. The furnace temperature is controlled by a thermocouple located in the upper middle part of the furnace tube. A gas supply system, including two gas flow controllers, one liquid flow controller (for liquid water) and a controlled evaporator mixer unit (CEM), is used to define the atmosphere. A quadrupole mass spectrometer (Balzers GAM 300) is installed to measure the composition of the off-gas during experiments. The specimens were placed in an alumina boat. During the experimental process, the specimens were first heated to $1200^{\circ} \mathrm{C}$ in high purity $\operatorname{Ar}(6 \mathrm{~N})$ atmosphere with a gas flow rate of $20 \mathrm{l} / \mathrm{h} \mathrm{Ar}$, then the atmosphere was changed to $20 \mathrm{l} / \mathrm{h} \mathrm{Ar}$ and $20 \mathrm{~g} / \mathrm{h}$ $\mathrm{H}_{2} \mathrm{O}$ (resulting in $\sim 55$ vol.\% $\mathrm{H}_{2} \mathrm{O}$ ) for steam oxidation. The specimens were isothermally oxidized in a flowing argon plus steam atmosphere. Argon plays the role of carrier gas and the reference gas for mass spectrometer analysis. Finally, after the 1 hour isothermal exposure, the specimens were cooled down to room temperature by simultaneously changing the atmosphere back to high purity Ar with $20 \mathrm{l} / \mathrm{h} \mathrm{Ar}$ flow rate. The heating and cooling rates were kept at $10 \mathrm{~K} / \mathrm{min}$. The off-gas tube from the furnace to the mass spectrometer is heated to about $150{ }^{\circ} \mathrm{C}$ to prevent steam condensation. The mass spectrometer is calibrated for $\mathrm{H}_{2}$ with certificated $\mathrm{Ar}-\mathrm{H}_{2}$ gas mixtures. The hydrogen release rate gives in-situ information about the kinetics of the oxidation reaction $x M(s)+y H_{2} \mathrm{O}(g) \rightarrow \mathrm{M}_{x} \mathrm{O}_{y}(\mathrm{~s})+\mathrm{yH}_{2}(\mathrm{~g})$.

Before and after oxidation, the mass of the specimens is measured using an analytical balance. The microstructure of the fresh and oxidized model alloys is characterized by scanning electron microscopy (SEM, Philips XL 40 SEM and Hitachi S-4800), equipped with energy dispersive X-ray spectroscopy (EDS). The phase composition of samples is analyzed by X-ray diffraction (XRD, Seifert PAD II) with Cu Ka1 
radiation $(\lambda=0.15406 \mathrm{~nm}, 40 \mathrm{kV}$ and $30 \mathrm{~mA})$ in Bragg-Brentano geometry $(\theta-2 \theta)$ with a step size of $0.002^{\circ}$ and a scan speed of $1 \% \mathrm{~min}$.

\section{Results}

\subsection{Microstructure characterization before oxidation test}

\subsubsection{AFA alloys}

Fig. 1 shows the microstructure and XRD pattern of AFA model alloys after annealing heat treatment. All samples contain large grains with grain size around 200-500 $\mu \mathrm{m}$. AFA-1 sample shows Al-Ni-rich precipitates mainly at the grain boundaries according to the microstructure and EDS analysis, as shown in Fig. 1(a). Further analysis by XRD confirms the formation of B2-NiAl phase (PDF no. 44-1267) besides the austenitic FCC solid solution (PDF no. 33-397), as shown in Fig. 1(d). AFA-2 and AFA-3 show a single phase matrix with some Y-Ni-Al-rich precipitates (diameter 4-10 $\mu \mathrm{m}$ ), an effect of the yttrium over doping, see Fig. 1(b) and (c). According to the XRD characterization, only a FCC solid solution is identified as the alloy matrix.
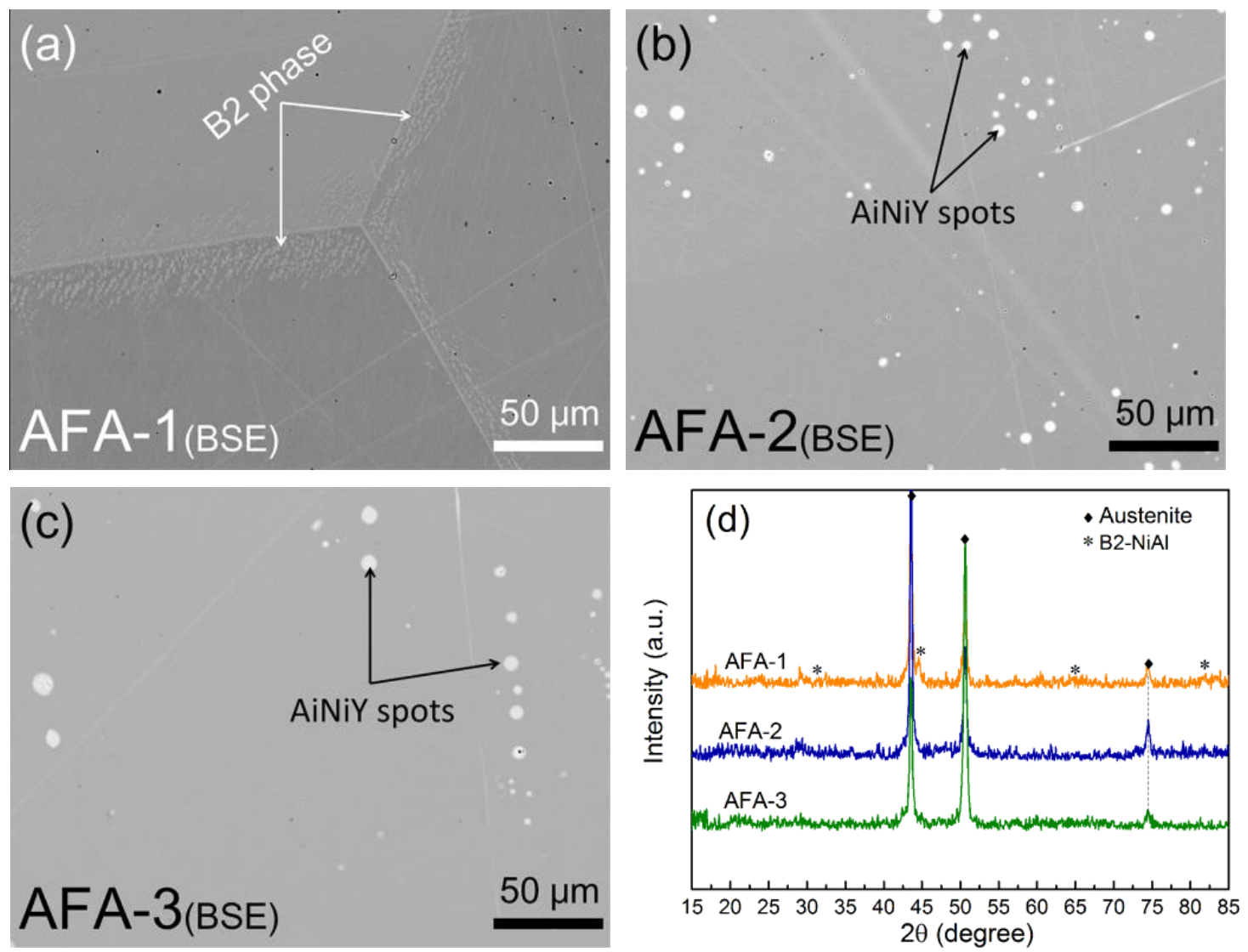

Fig. 1 SEM images of annealed AFA model alloys (BSE: back scattered electron image), (a): AFA-1; (b): AFA-2; (c): AFA-3; (d): XRD patterns of AFA alloys.

\subsubsection{HEA alloys}

Fig. 2 shows the microstructure and XRD analysis of as cast HEA model alloys. HEA- 1 has formed single phase with a grain size of around 200-500 $\mu \mathrm{m}$. In case of HEA2, Al-Ni-rich second phase precipitates are 
observed in the matrix. Both HEA-3 and HEA-4 with addition of $\mathrm{Nb}$ and $\mathrm{Ti}$, respectively, show a microstructure with dendrite morphology (Fig. 2(c) and Fig. 2(d)). According to the EDS measurements summarized in Table 2, $\mathrm{Nb}$ is enriched at the inter-dendrites of HEA-3. The concentration of $\mathrm{Al}$ in interdendrites (ID) is close to the value in dendrites (D). HEA-4 shows the enrichment of $\mathrm{Al}, \mathrm{Ti}$ and $\mathrm{Ni}$ at the inter-dendrites (ID). Fig. 2(e) shows the X-ray diffraction pattern of as cast HEA alloys. Only austenite is identified from HEA-1 and HEA-2. The B2-NiAl precipitates observed in HEA-2 (Fig. 2(b)) could not be detected by XRD due to their low fraction ( $<5$ vol.\%) in the alloy matrix. The phase composition of HEA-3 consists of FCC and $\mathrm{Fe}_{2} \mathrm{Nb}$ Laves phase (PDF no.17-908), while HEA-4 has formed FCC as the matrix with $\gamma^{\prime}-\mathrm{Ni}_{3}(\mathrm{Al}, \mathrm{Ti})$ (PDF no.18-872) precipitates.
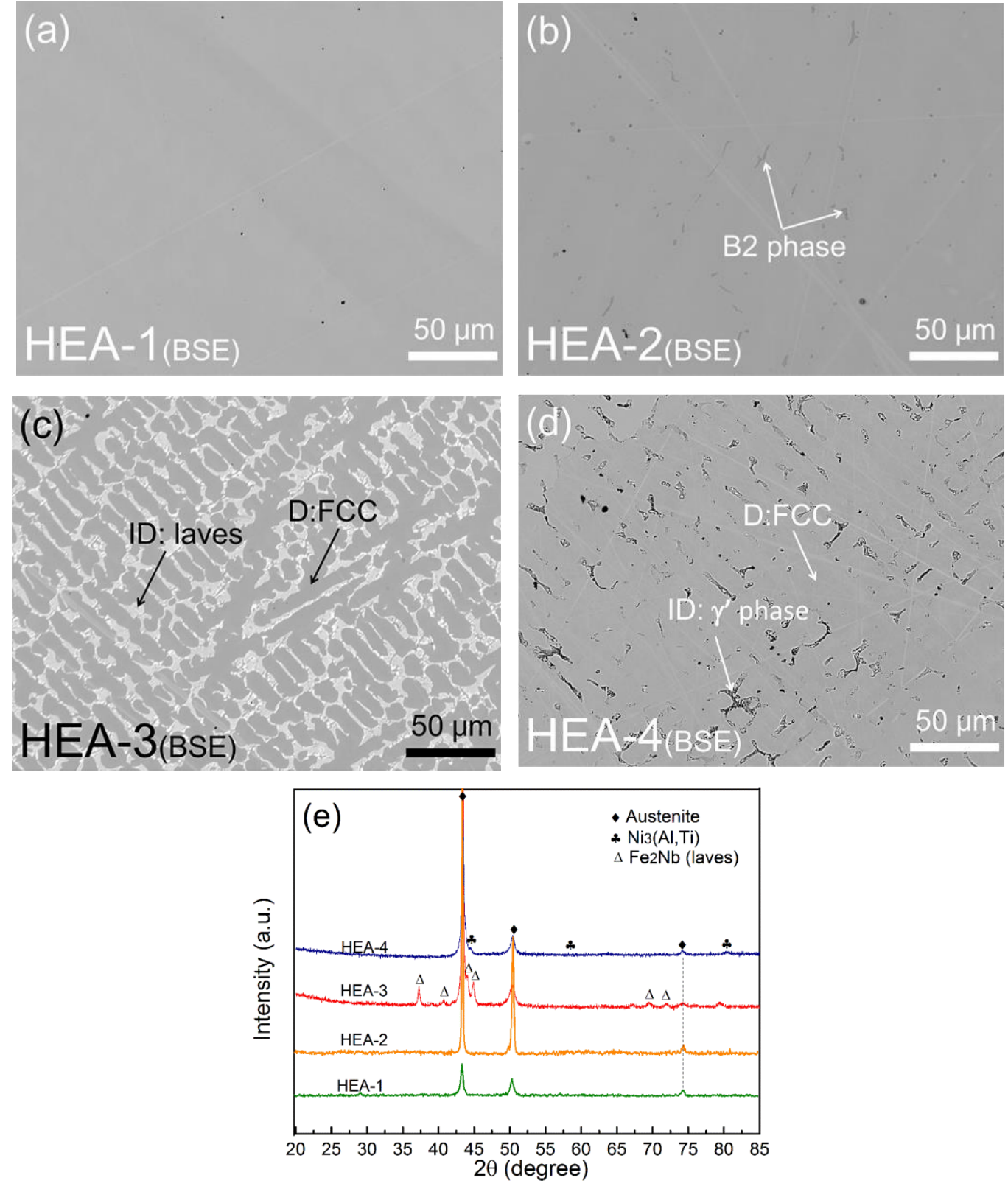

Fig. 2 SEM images of as cast HEA model alloys (D: dendrite; ID: inter-dendrite; BSE: back scattered electron image): (a): HEA-1; (b): HEA-2; (c): HEA-3; (d): HEA-4; (e): XRD patterns of as-cast HEA alloys. 


\subsection{Oxidation test in steam}

\subsubsection{Oxidation behavior of AFA alloys}

\subsubsection{Mass gain and hydrogen release}

The mass of the test samples has been recorded before and after the steam oxidation. Table 3 shows the mass gain of AFA samples oxidized in steam at $1200^{\circ} \mathrm{C}$, as well as the mass gain of two FeCrAl alloys as a reference. The mass gain of AFA model alloys is comparable to that of the FeCrAl alloys. AFA- 1 exhibits the least mass gain. On the other hand, AFA-1 also shows the evidence of oxide scale spallation as described below.

Table 3 Mass gain and total amount of hydrogen release of AFA samples after $1 \mathrm{~h}$ exposure in steam at $1200{ }^{\circ} \mathrm{C}$. The mass gain of two FeCrAl alloys is added as reference.

\begin{tabular}{llllll}
\hline Sample & AFA-1 & AFA-2 & AFA-3 & $\begin{array}{l}\text { Fe-13Cr-4Al-base (wt.\%) } \\
(w t . \%) ~[55]\end{array}$ & APMT [56] \\
\hline $\begin{array}{l}\text { Mass gain } \\
\left(\mathrm{mg} / \mathrm{cm}^{2}\right)\end{array}$ & 0.16 & 0.65 & 0.34 & 0.4 & 0.2 (1bar, steam) \\
$\begin{array}{l}\text { Total hydrogen } \\
\text { Release }\left(\mathrm{mg} / \mathrm{cm}^{2}\right)\end{array}$ & 0.28 & 0.29 & 0.36 & --- & -- \\
\hline
\end{tabular}

Hydrogen release is recorded to qualitatively investigate the oxidation kinetics in steam condition. Fig. 3 shows the real-time hydrogen release rate of AFA model alloys during oxidation test. AFA- 1 shows a relatively low hydrogen release rate with a value lower than $0.0025 \mathrm{~g} / \mathrm{s} / \mathrm{m}^{2}$ at the initial $600 \mathrm{~s}$ of the oxidation test. Then it increases slowly to $0.0025 \mathrm{~g} / \mathrm{s} / \mathrm{m}^{2}$ during the later exposure time. Compared with AFA-1, both AFA-2 and AFA-3 show a large increase in the hydrogen release rate at the initial $150 \mathrm{~s}$. Then it decreases to a value below $0.0025 \mathrm{~g} / \mathrm{s} / \mathrm{m}^{2}$ at $600 \mathrm{~s}$ and finally slowly increases until the end of the test. The integral amount of released hydrogen after 1 hour exposure to steam is given in Table 3 .

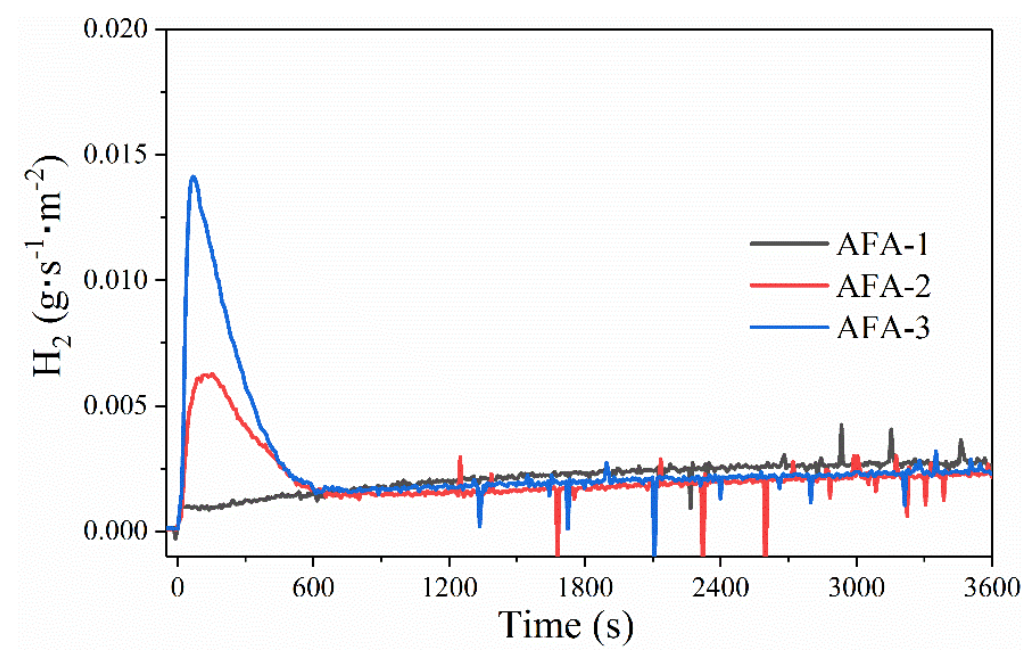

Fig. 3 Hydrogen release rate of AFA samples exposed to steam atmosphere at $1200^{\circ} \mathrm{C}$.

3.2.1.2 Surface and cross section analysis 
Fig. 4 shows the typical surface view of the AFA model alloys after $1 \mathrm{~h}$ exposure to steam at $1200^{\circ} \mathrm{C}$. The oxide scale formed on AFA-1 displays wrinkle morphology, see Fig. 4 (a). Nearly $30 \%$ of the surface scale suffers from the cracks and exfoliations. Below the spalled oxide scale part, no further oxidation is observed. In contrast, the surface of AFA-2 is covered by a smooth oxide scale without any exfoliation. EDS point measurements show the enrichment of $A l$ and $O$ on the surface, indicating the formation of alumina. In case of AFA-3, the formed oxide scale shows the morphologies similar to AFA-2. In addition to the Al-rich surface layer, a few protrusions are also observed among the surface of AFA-2 and AFA-3, as shown in Fig. 4 (b, c). As evidenced by EDS points measurements, they are $\mathrm{Cr}$-rich oxide (e.g. $\mathrm{Cr}_{2} \mathrm{O}_{3}$, $\left.(\mathrm{Fe}, \mathrm{Cr})_{3} \mathrm{O}_{4}\right)$ spots. These $\mathrm{Cr}$-rich oxides grow at the Al-depleted regions surrounding the AlNiY-rich precipitates.
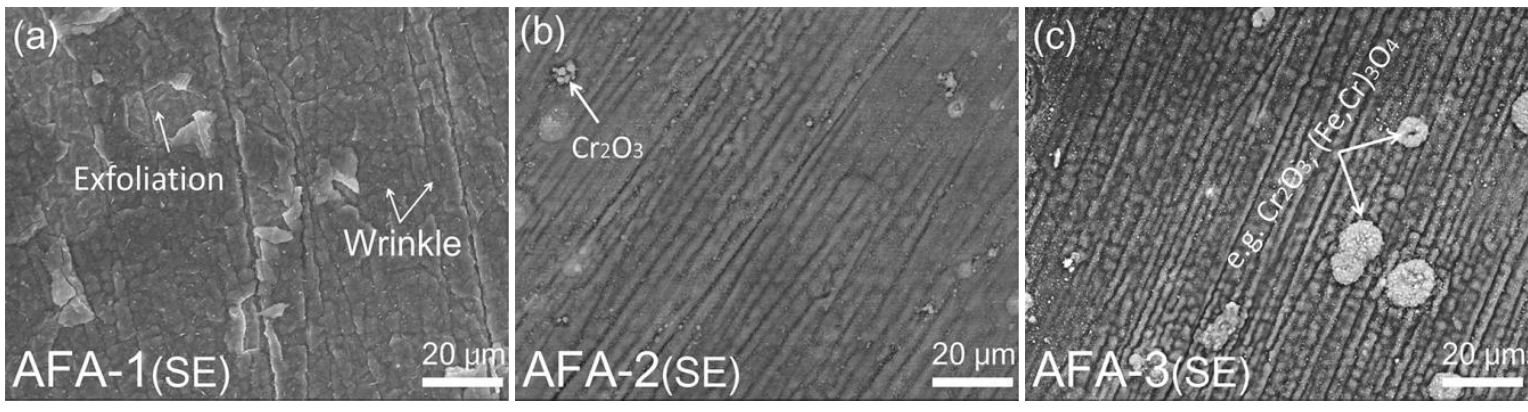

Fig. 4 SEM surface morphologies of AFA samples after $1 \mathrm{~h}$ exposure to steam at $1200{ }^{\circ} \mathrm{C}$ (SE: secondary electron image).

Cross section analysis of the oxide scale is shown in Fig. 5. A thin oxide scale with deformations is observed at the cross section of AFA-1. According to the EDS line scanning analysis, only the maxima of Al and $O$ signals are detected in the oxide scale region. The thickness of the oxide scale is around 1.75-1.8 $\mu \mathrm{m}$. Besides, a depletion of secondary B2-NiAl phase, around $6 \mu \mathrm{m}$ in depth, is clearly observed below the oxide scale. AFA-2 and AFA-3 have formed a continuous oxide scale. Based on the EDS measurements, the oxide scale consists of $O$ and Al, see Fig. 5 and Fig. 6 . The thickness of the oxide scale formed on AFA-2 and AFA-3 is around 1.25-1.3 $\mu \mathrm{m}$. 

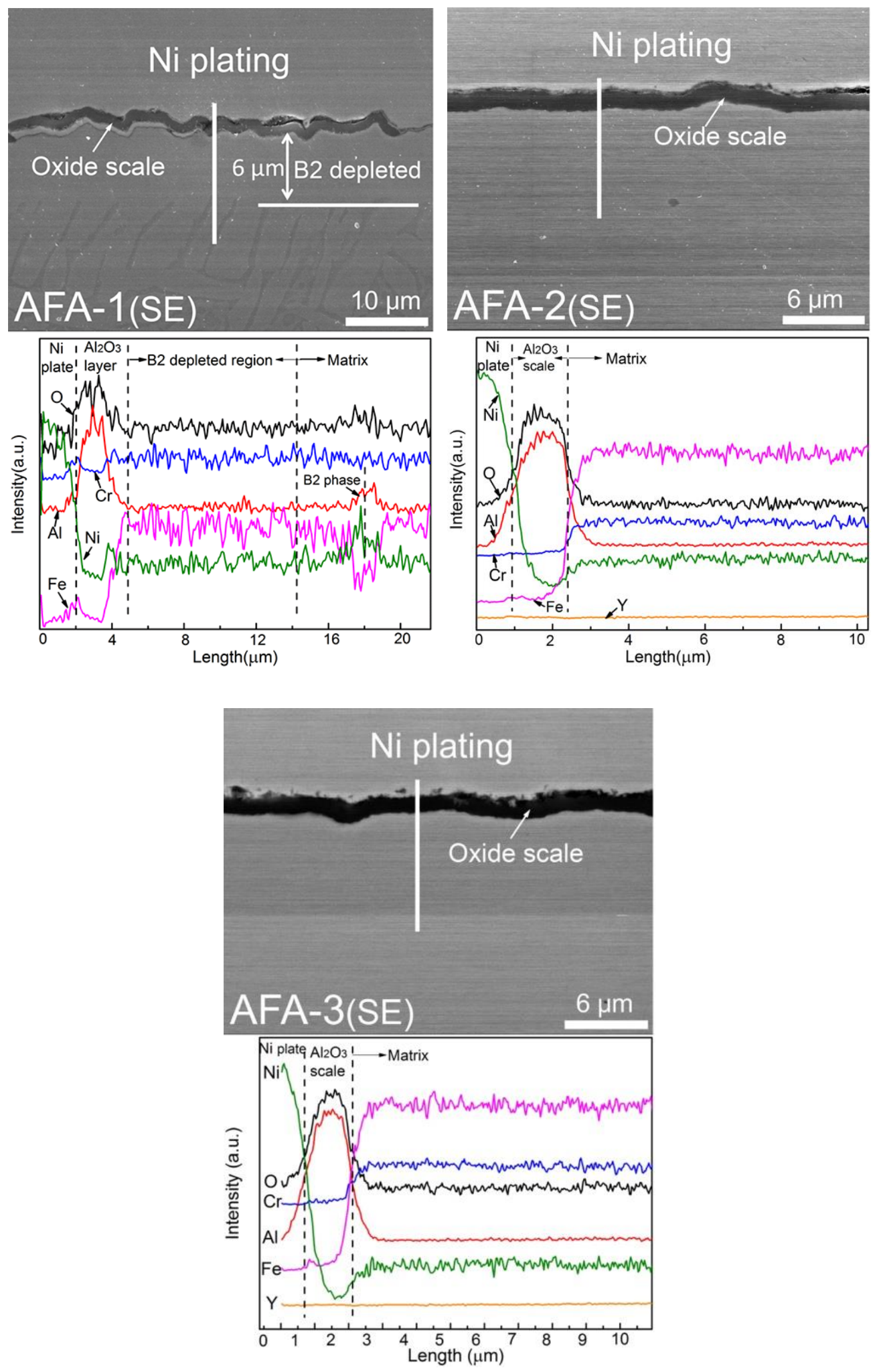

Fig. 5 Representative SEM cross section images and corresponding EDS line scanning of oxide scales grown on AFA samples after $1 \mathrm{~h}$ exposure to steam at $1200^{\circ} \mathrm{C}$. 


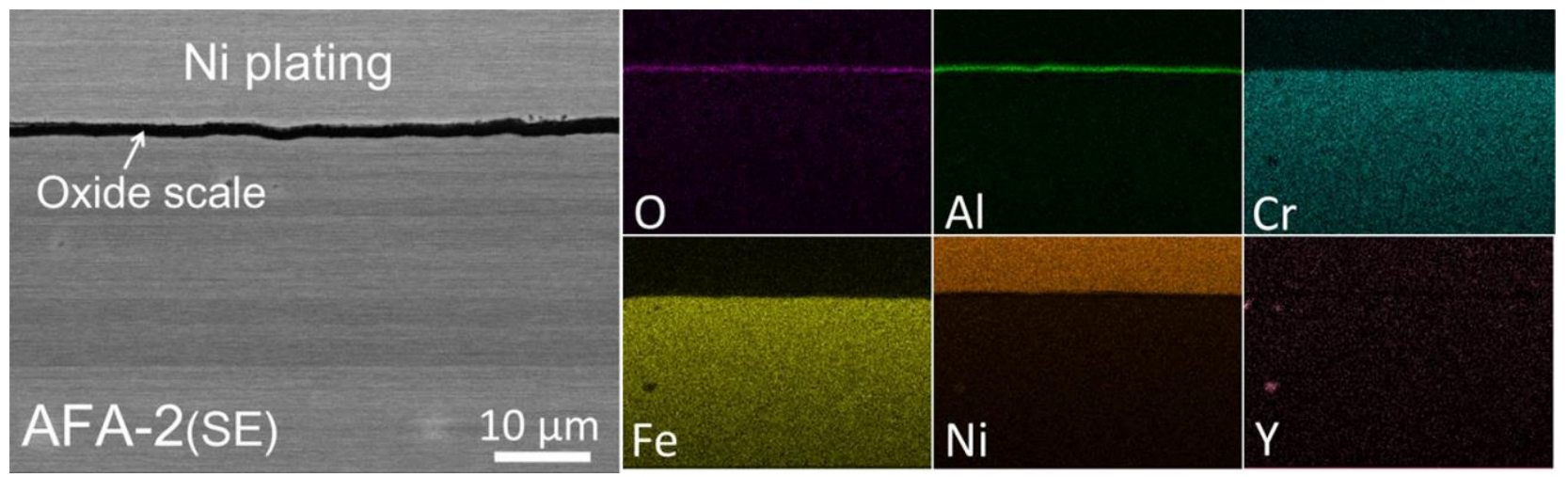

Fig. 6 Representative EDS elemental mapping of AFA-2 after $1 \mathrm{~h}$ exposure to steam at $1200^{\circ} \mathrm{C}$.

\subsubsection{XRD characterization}

Fig. 7 shows the XRD pattern of AFA samples after the oxidation test. X-ray diffraction pattern analysis of AFA- 1 confirms the formation of thermodynamically stable $\alpha-\mathrm{Al}_{2} \mathrm{O}_{3}$ (corundum, PDF no: 46-1212) and $\mathrm{B} 2-\mathrm{NiAl}$ phase plus FCC solid solution. The phases identified from AFA-2 consist of $\alpha-\mathrm{Al}_{2} \mathrm{O}_{3}, \mathrm{Cr}_{2} \mathrm{O}_{3}$ ( $\mathrm{PDF}$ no: 84-1616), $(\mathrm{Fe}, \mathrm{Cr})_{3} \mathrm{O}_{4}$ (PDF no. 34-140) and FCC solid solution. AFA-3 shows the signals from $\alpha-\mathrm{Al}_{2} \mathrm{O}_{3}, \mathrm{Cr}_{2} \mathrm{O}_{3}$, ( $\mathrm{Fe}, \mathrm{Cr})_{3} \mathrm{O}_{4}$ (PDF no. 34-140) and $\mathrm{FCC}$ solid solution. The signals from $\mathrm{Cr}_{2} \mathrm{O}_{3}$ are stronger than that observed on AFA-2. Besides, The $\mathrm{Cr}$-rich oxides $\left(\mathrm{Cr}_{2} \mathrm{O}_{3},(\mathrm{Fe}, \mathrm{Cr})_{3} \mathrm{O}_{4}\right)$ identified from XRD are from the protrusions which grows around the AlNiY-rich compounds, where the $\mathrm{Al}$ is depleted.

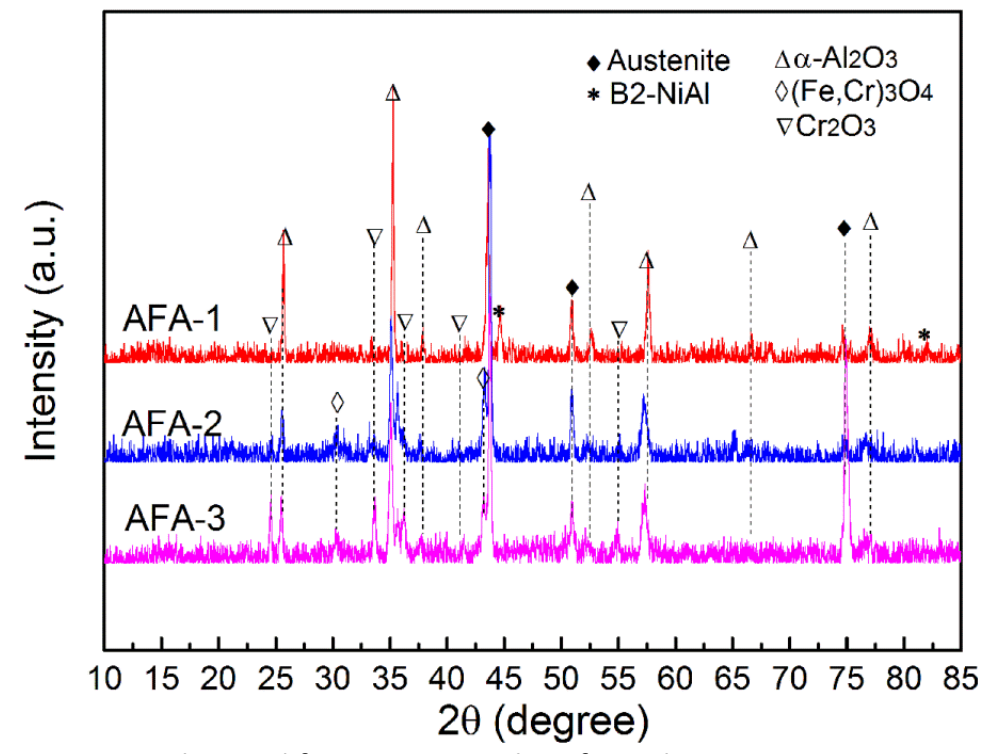

Fig. 7 XRD patterns obtained from AFA samples after $1 \mathrm{~h}$ exposure to steam at $1200^{\circ} \mathrm{C}$.

\subsubsection{Oxidation behavior of HEA alloys}

\subsubsection{Mass gain and hydrogen release}

Table 4 shows the mass gain of HEA samples after oxidation test in steam at $1200^{\circ} \mathrm{C}$. HEA- 1 and HEA2 exhibit a mass gain lower than that of HEA-3. HEA-4 shows by far the largest mass gain among the HEA alloys, even 3.5 times larger than that of HEA-3. 
Table 4 Mass gain and total hydrogen release of HEA samples after $1 \mathrm{~h}$ exposure in steam at $1200^{\circ} \mathrm{C}$.

\begin{tabular}{lllll}
\hline Sample & HEA-1 & HEA-2 & HEA-3 & HEA-4 \\
\hline $\begin{array}{l}\text { Mass gain } \\
\left(\mathrm{mg} / \mathrm{cm}^{2}\right)\end{array}$ & 0.39 & 0.24 & 0.72 & 2.66 \\
$\begin{array}{l}\text { Total hydrogen } \\
\text { release }\left(\mathrm{mg} / \mathrm{cm}^{2}\right)\end{array}$ & 0.50 & 0.43 & 0.22 & 0.45 \\
\hline
\end{tabular}

Fig. 8 shows the real-time hydrogen release of HEA model alloys during exposure to steam at $1200^{\circ} \mathrm{C}$. HEA-1 and HEA-2 show a similar temporal evolution of the hydrogen release rate. At the initial exposure stage $(<600 \mathrm{~s})$, both samples show the hydrogen release rate lower than $0.001 \mathrm{~g} / \mathrm{s} / \mathrm{m}^{2}$. Then, it increases slowly to $0.002-0.003 \mathrm{~g} / \mathrm{s} / \mathrm{m}^{2}$ till the end of the test, see Fig. 8. After $1800 \mathrm{~s}$, the hydrogen release rate of HEA-2 is lower than that of HEA-1. HEA3 shows a small peak of hydrogen release with a rate of 0.002 $\mathrm{g} / \mathrm{s} / \mathrm{m}^{2}$ at $100 \mathrm{~s}$. Then, it decreases rapidly to around $0.001 \mathrm{~g} / \mathrm{s} / \mathrm{m}^{2}$ at $150 \mathrm{~s}$ and remains nearly constant at a value well below that of HEA-1 and HEA-2. HEA-4 shows a dramatic increase of hydrogen release rate during the initial $300 \mathrm{~s}$ with a peak rate of $0.0125 \mathrm{~g} / \mathrm{s} / \mathrm{m}^{2}$ after $100 \mathrm{~s}$. Then, the hydrogen release rate decreases to a low value around $0.0015 \mathrm{~g} / \mathrm{s} / \mathrm{m}^{2}$ at $900 \mathrm{~s}$, where it stays for the rest of the oxidation test. The integral hydrogen release after $1 \mathrm{~h}$ exposure amounts to the values given in Table 4.

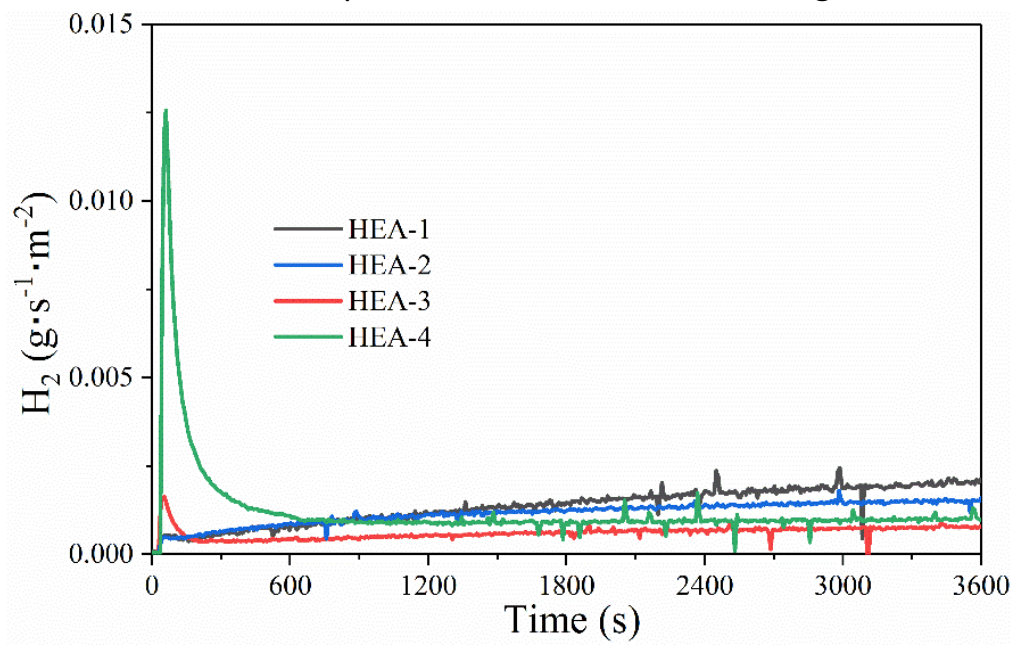

Fig. 8 Hydrogen release rate of HEA samples exposed to steam atmosphere at $1200^{\circ} \mathrm{C}$.

\subsubsection{Surface and cross section analysis}

Fig. 9 shows the typical surface view of HEA model alloys after oxidation test. The surface of HEA-1 is covered by a thin oxide scale. Parts of the scale spall off and the uncovered regions show bright contrast. The semi-quantitative EDS point measurement of the remaining oxide scale (Fig. 9 (a-1)) shows enrichment of $\mathrm{O}$ and Al. Besides, a few oxide protrusions ( $<2 \%$ surface area) are also visible (see Fig. 9 (a2)). EDS measurements of these spots indicate the enrichment of $\mathrm{O}$ and $\mathrm{Cr}$. The surface analysis of HEA-2 shows the wrinkle morphology of the oxide scale. Part of the layer $(<25 \%$ surface area) suffers from exfoliation, see the bright aspect in Fig. 9 (b). The surface of HEA-3 is covered by a uniform oxide scale after oxidation test. Only some spots, around $5 \%$ of the surface area, show exfoliation. EDS point 
measurements of the oxide scale indicate the formation of Al-rich oxide scale. The oxide layer formed on HEA-4 presents different features. For instance, the layer formed on top, also called outer layer, shows exfoliation at some regions. The remaining part measured by EDS shows the enrichment of $\mathrm{O}, \mathrm{Ti}$ and Fe. At the spallation area, an inner oxide layer featured in small grains is observed. EDS analysis indicates that the inner layer mainly consists of $\mathrm{O}, \mathrm{Cr}$ and $\mathrm{Fe}$.
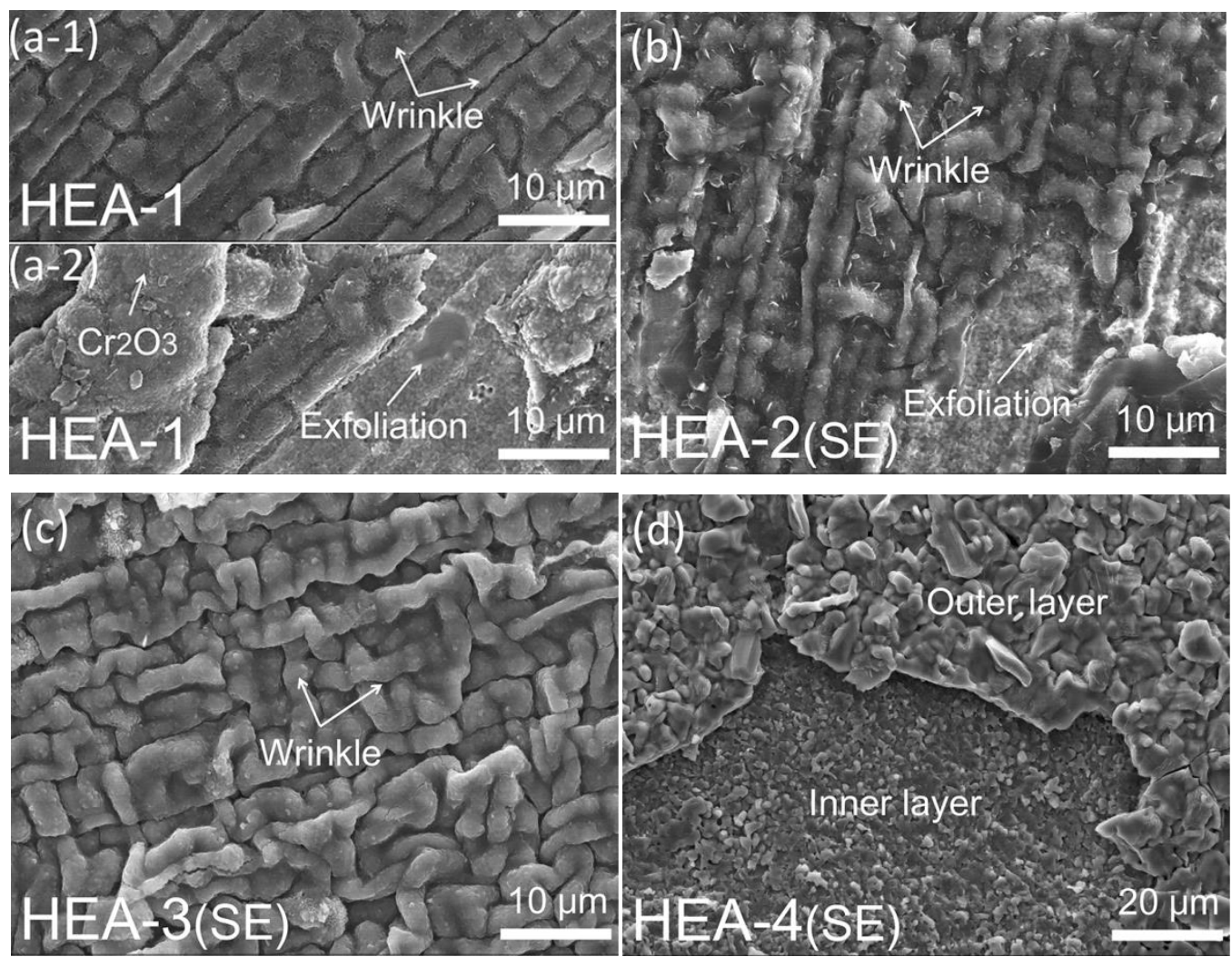

Fig. 9 SEM Surface morphologies of HEA samples after $1 \mathrm{~h}$ exposure to steam at $1200^{\circ} \mathrm{C}$.

Cross section evaluation of HEA-1 and HEA-2 is shown in Fig. 10. Both samples have formed a uniform and thin oxide scale. EDS line scanning of both layers shows the coincidence of the maxima of $\mathrm{O}$ and $\mathrm{Al}$ signals in the oxide scale. The thickness of the oxide scale formed on HEA-1 is around $1.6 \mu \mathrm{m}$, while the surface of HEA-2 is passivated by a thinner layer with a thickness of $1.3 \mu \mathrm{m}$. As for the structure in the alloy matrix, no second phase is observed neither from morphology nor from EDS analysis of HEA-1. HEA2 shows the depletion of B2-NiAl inter-dendrite precipitates up to $20 \mu \mathrm{m}$ below the oxide scale. 

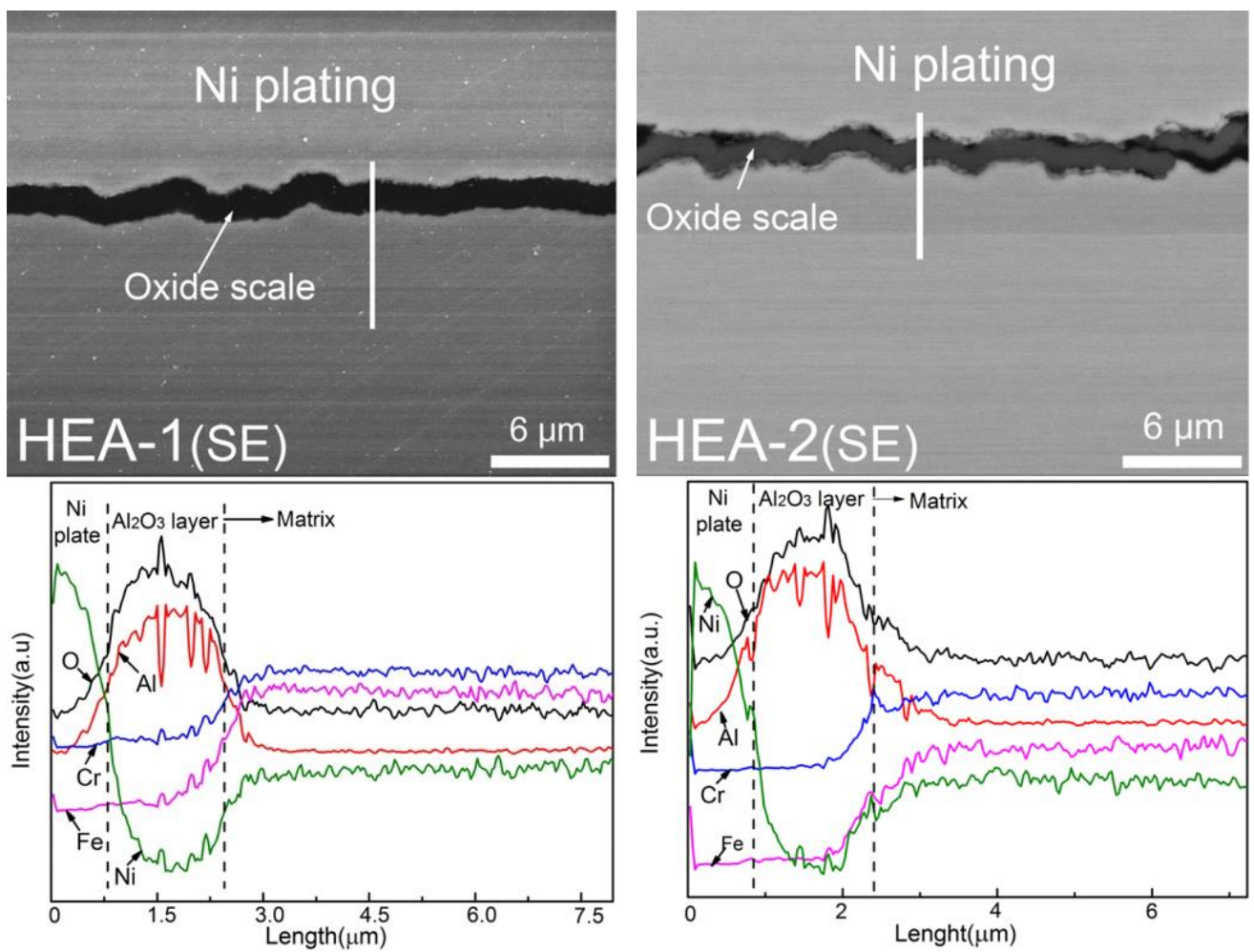

Fig. 10 Representative SEM cross section images and corresponding EDS line scanning of oxide scale grown on HEA-1 and HEA-2 samples after $1 \mathrm{~h}$ exposure to steam at $1200{ }^{\circ} \mathrm{C}$.

In the cross section of HEA-3 (Fig. 11), a compact oxide scale with deformation is observed. Both EDS line scan and elemental mapping confirm the enrichment of $\mathrm{O}$ and $\mathrm{Al}$ in the oxide scale, see Fig. 11 and Fig. 12. Moreover, the oxide scale also formed above the Nb-rich laves phase, as shown in Fig. 11 . The thickness of the oxide scale is around 1.28-1.3 $\mu \mathrm{m}$. As for the oxide layer formed on HEA-4, cross section analysis reveals a triple-layered structure. According to EDS measurement, the outer layer accompanied by spallation is Ti-rich and Fe-rich oxides. In the middle layer, which is underneath the outer layer, a thick and dense $\mathrm{Cr}$-rich oxide is formed. Below the $\mathrm{Cr}$-rich middle layer, internal oxidation of $\mathrm{Al}$ is detected by EDS analysis. The total thickness of the corrosion layer (including internal oxidation zone) is around $30 \mu \mathrm{m}$. Moreover, a layer with a depth of $20 \mu \mathrm{m}$, which is depleted in $\gamma^{\prime}-\mathrm{Ni}_{3}(\mathrm{Al}, \mathrm{Ti})$ phase, is observed below the Al-internal oxidation layer. 

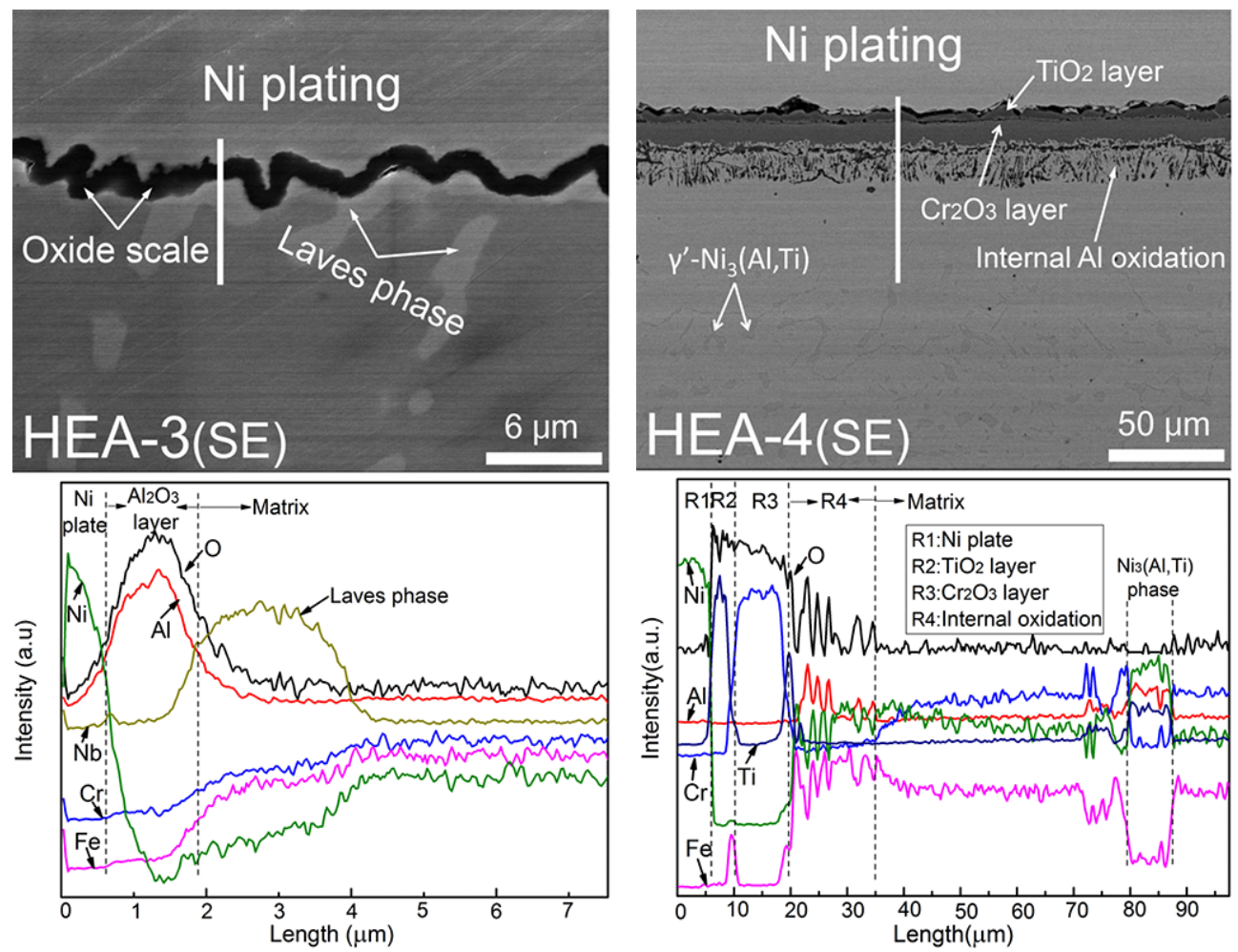

Fig 11. Representative SEM cross section image and corresponding EDS line scanning of oxide scale grown on HEA-3 and HEA-4 samples after $1 \mathrm{~h}$ exposure to steam at $1200^{\circ} \mathrm{C}$.

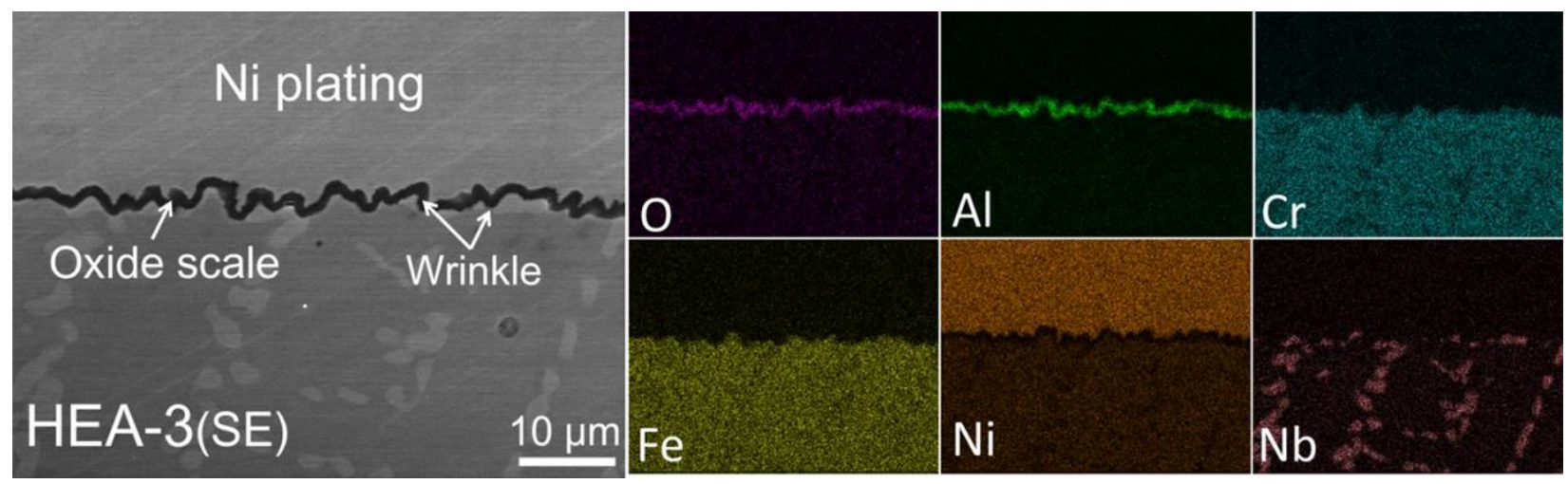

Fig. 12 Representative EDS elemental mapping of HEA-3 after $1 \mathrm{~h}$ exposure to steam at $1200^{\circ} \mathrm{C}$.

\subsubsection{XRD characterization}

Fig. 13 shows the X-ray diffraction pattern of HEA model alloys after oxidation in steam. HEA-1 shows the signals of $\alpha-\mathrm{Al}_{2} \mathrm{O}_{3}$, weak peaks from $\mathrm{Cr}_{2} \mathrm{O}_{3}$ and $\mathrm{FCC}$ solid solution. Combined with surface morphology (Fig. 9) and EDS analysis, the $\mathrm{Cr}_{2} \mathrm{O}_{3}$ phase is attributed to the observed protrusions. Both HEA-2 and HEA3 show strong signals from $\alpha-\mathrm{Al}_{2} \mathrm{O}_{3}$ and FCC solid solution. In HEA-3, the Laves phase reflections are still observed after the oxidation test. The oxides formed on HEA-4 mainly consist of $\mathrm{Cr}_{2} \mathrm{O}_{3}, \mathrm{Fe}_{3} \mathrm{O}_{4}$ and $\mathrm{TiO}_{2}$ (rutile, PDF card Nr: 4-551), while the phase composition of bulk alloy remains unchanged after the oxidation test, namely consisting of $\mathrm{FCC}$ and $\gamma^{\prime}-\mathrm{Ni}_{3}(\mathrm{Al}, \mathrm{Ti})$ phases. 


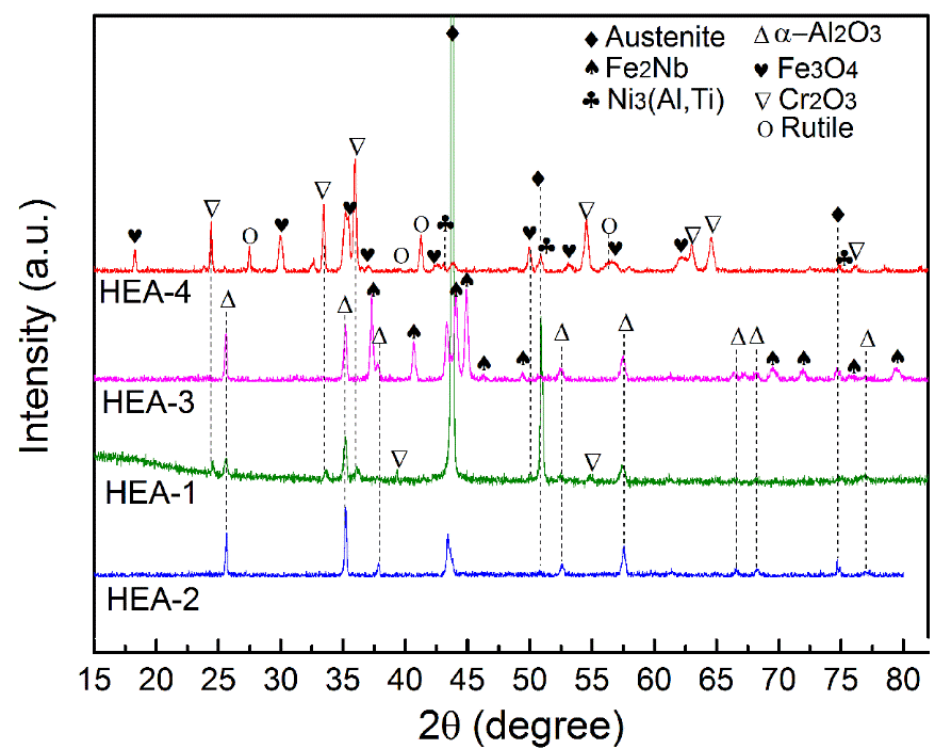

Fig. 13 XRD patterns obtained from HEA samples after $1 \mathrm{~h}$ exposure to steam at $1200^{\circ} \mathrm{C}$.

\section{Discussion}

The highest mass gain is found for HEA-4 $\left(2.66 \mathrm{mg} / \mathrm{cm}^{2}\right)$. This is consistent with the type of oxide scale grown on the alloys: HEA-4 exhibits a corrosion layer with a total thickness of about $30 \mu \mathrm{m}$, while the other alloys form a thin Al-rich oxide scale with a thickness below $2 \mu \mathrm{m}$. Allother samples These aluminaforming alloys show a mass gain in the range 0.2 to $0.7 \mathrm{mg} / \mathrm{cm}^{2}$, comparable with the values of the commercial or prototype $\mathrm{Fe}-\mathrm{Cr}$-Al-based alloys, indicating their excellent oxidation resistance. Due to exfoliation of the oxide scales, no further reliable information can be obtained from the mass gain measurements. Thermal gravimetric analysis (TGA) in steam-containing atmosphere is an option for a more accurate mass gain measurement.

The recorded hydrogen release rate during the first $600 \mathrm{~s}$ of the experiments offers important information about the early stage of the oxidation process of the tested alloys. Samples AFA-2, AFA-3, HEA-3 and HEA-4 have shown an intensified hydrogen release during the initial $300 \mathrm{~s}$, indicating a fast oxidation process, followed by a decreasing signal. The highest hydrogen release rate of AFA-3 and HEA4 is attributed to the formation of less protective $\mathrm{Cr}_{2} \mathrm{O}_{3}$ and $(\mathrm{Fe}, \mathrm{Cr})_{3} \mathrm{O}_{4}$ and $\mathrm{TiO}_{2}$ (only in $\mathrm{HEA}-4$ ). After 600 s oxidation, AFA-2, AFA-3 and HEA-3 have shown relatively low hydrogen release rate due to the formation of protective $\alpha-\mathrm{Al}_{2} \mathrm{O}_{3}$ scale. The limited accuracy of the data and large sources of error (see below) do not allow further conclusions for time above $600 \mathrm{~s}$. Moreover, the higher Ni content in AFA-3 may delay the formation of a continuous alumina scale [57]. In contrast, AFA-1, HEA-1 and HEA-2 have shown a moderate evolution of hydrogen release without the characteristic peak of intensified hydrogen release in the initial stage. The low hydrogen release during the initial $600 \mathrm{~s}$ can be attributed to the very early formation of thin $\mathrm{Al}_{2} \mathrm{O}_{3}$ rich scale, which effectively reduces the inward oxygen and outward alloy elements diffusion (e.g. $\mathrm{Fe}, \mathrm{Cr}$ ).

The total amount of hydrogen released during $1 \mathrm{~h}$ exposure to steam is between 0.22 and $0.5 \mathrm{mg} / \mathrm{cm}^{2}$ for all samples. If oxidation was the only process generating free $\mathrm{H}_{2}$ gas, the expected mass gain due to oxygen incorporation into the oxide scale is a factor of 8 higher than the released amount of $\mathrm{H}_{2}$, i.e., 1.8- 
$4.0 \mathrm{mg} / \mathrm{cm}^{2}$. This is much more than the measured mass gain and the mass gain estimated from the observed oxide scales. Responsible for this discrepancy could be further decomposition and/or dissociation of $\mathrm{H}_{2} \mathrm{O}$, volatilization of hydroxides, loss of oxides, and an uncertainty of the measurement for very low hydrogen concentration [58-59].

In pure steam environment, the oxygen consumed during oxidation is from the decomposition of $\mathrm{H}_{2} \mathrm{O}$ [60-61]. Only if the oxygen partial pressure is higher than the dissociation partial pressure of the oxide, the metal will be consumed to form oxides [6]. Based on thermodynamic calculations (performed with HSC Chemistry 9 code [62]), the oxygen partial pressure generated by steam dissociation and the dissociation oxygen partial pressure of selected oxides have been determined within this research work. The following Fig. 14 is drawn to describe the relationship between the oxygen partial pressure of selected oxides formation and steam dissociation as a function of temperature. According to the diagram, the oxygen dissociation partial pressures of metal oxides like $\mathrm{Al}_{2} \mathrm{O}_{3}, \mathrm{TiO}_{2}, \mathrm{Nb}_{2} \mathrm{O}_{5}, \mathrm{Cr}_{2} \mathrm{O}_{3}$ and $\mathrm{Fe}_{3} \mathrm{O}_{4}$ are lower than the oxygen partial pressure of steam ( 0.5 bar) at $900-1300{ }^{\circ} \mathrm{C}$. Metal oxide $\mathrm{NiO}$ has lower oxygen dissociation partial pressure than that of steam only below $1200{ }^{\circ} \mathrm{C}$.

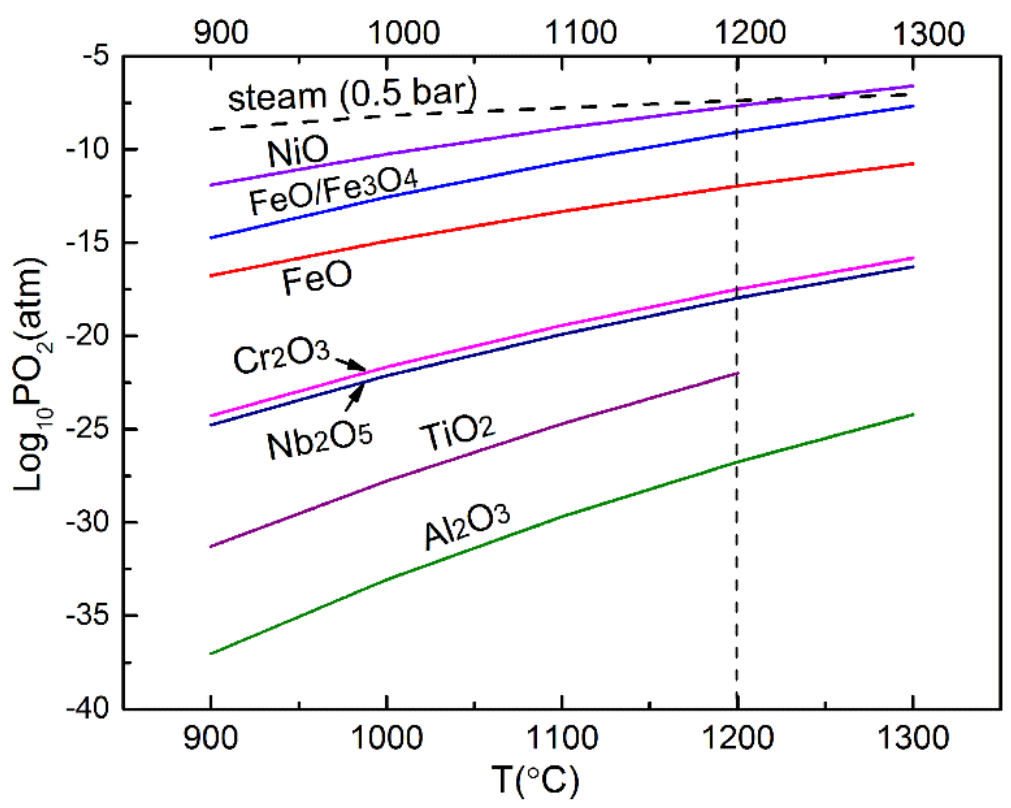

Fig. 14 Equilibrium oxygen partial pressures of selected oxides and dissociation oxygen pressure of steam as a function of temperature (oxygen partial pressure is calculated by HSC Chemistry 9 [62]).

Fig. 15 illustrates the process of $\alpha-\mathrm{Al}_{2} \mathrm{O}_{3}$ scale formation and oxide scale spallation (during cooling) of Y-free alumina-forming alloys when exposed to steam at $120{ }^{\circ} \mathrm{C}$. At the beginning of the exposure, elements like $\mathrm{Fe}, \mathrm{Cr}, \mathrm{Al}$ and $\mathrm{Nb}$ will be oxidized to form an initial thin oxide scale. Then the oxygen partial pressure at the scale-alloy interface is significantly reduced. Therefore, aluminum from the alloy is primarily oxidized due to the lowest dissociation oxygen partial pressure of $\mathrm{Al}_{2} \mathrm{O}_{3}$, see Fig. 14. During the isothermal oxidation stage, both inward $\mathrm{O}$ diffusion and outward Al diffusion occur in Y-free aluminaforming alloys. [63-65]. The stress produced due to the lateral growth of the oxide scale leads to the convoluted morphology of the alumina scale [66-67]. The residual stress generated during oxide scale 
formation and the mismatch of the thermal expansion between austenitic phase (coefficient of thermal expansion (CTE): $14 * 10^{-6}-22 * 10^{-6}$ at $300-1500 \mathrm{~K},[68]$ ) and $\alpha-\mathrm{Al}_{2} \mathrm{O}_{3}$ scale (CTE: $6 * 10^{-6}-10^{*} 10^{-6}$, [69]) result in the cracking or even exfoliation of the alumina scale after exposure test [67]. The oxide scale exfoliation observed is indeed attributed to the cooling process, because the areas uncovered by exfoliation have a shiny aspect and do not show any sign of further oxidation.

HEA-4 alloyed with $\mathrm{Ti}$ shows the formation of outer $(\mathrm{Ti}, \mathrm{Fe}) \mathrm{O}_{2}$ layer. Titanium is preferentially oxidized to form a fast growing but less protective $\mathrm{TiO}_{2}$ layer due to the higher activity of $\mathrm{Ti}$ in Ti-Al containing alloys [70]. Moreover, Ti addition increases the solubility of oxygen in alloy matrix which promotes the internal oxidation of $\mathrm{Al}$ [71]. This result indicates that $\mathrm{Ti}$ addition degrades the oxidation resistance of alumina forming alloys in steam environments.

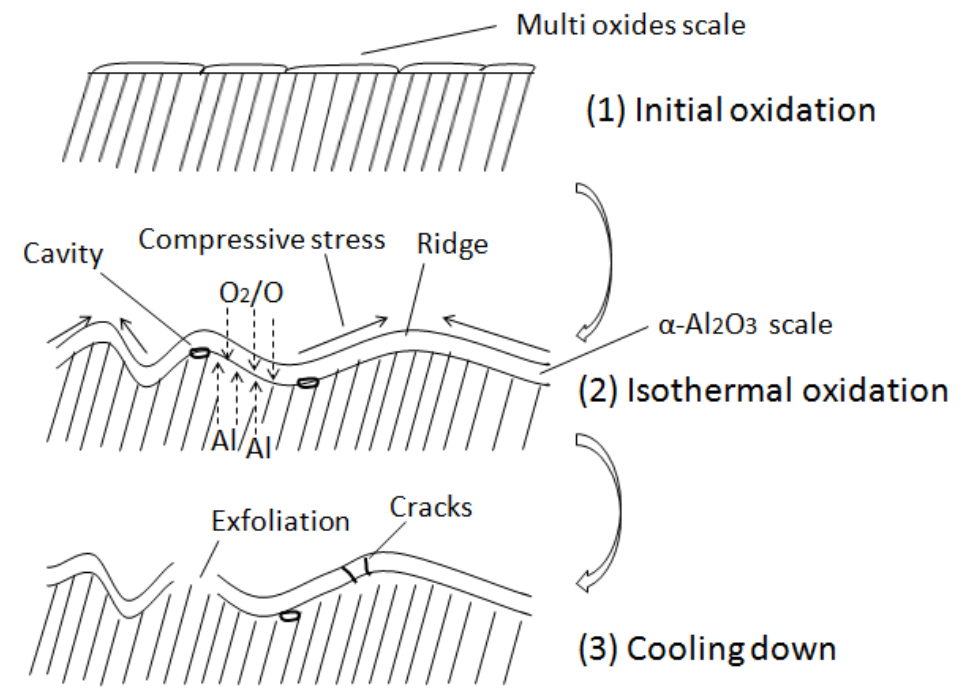

Fig. 15 Schematic process of $\alpha-\mathrm{Al}_{2} \mathrm{O}_{3}$ scale formation and scale degradation of alumina forming alloys exposed to steam environments at $1200^{\circ} \mathrm{C}$ for $1 \mathrm{~h}$.

Sample AFA-1 forms high quantities of ridges and displays large area of oxide scale exfoliation when compared with AFA-2 and AFA-3. Adding yttrium can inhibit the wrinkles formation and exfoliation of $\alpha$ $\mathrm{Al}_{2} \mathrm{O}_{3}$ scale. Possible explanations include (1) reduction of the growth stress by yttrium, (2) prevention of creep of the scale and (3) retardation of the lateral growth of the oxide scale [72-73]. In addition, the thinner scale formed on AFA- 2 and AFA-3 indicates the positive role of $Y$ also in reducing the growth rate of alumina scale.

Adding $\mathrm{Nb}$ (HEA-3) does not prevent the formation of ridges on $\alpha-\mathrm{Al}_{2} \mathrm{O}_{3}$ scale, even likely promotes the concave structures of the scale when compared with HEA-1 and HEA-2, as shown in Fig. 10 and Fig. 11. However, HEA-3 has formed the protective oxide scale with less spallation, indicating the positive effect of $\mathrm{Nb}$ on scale adherence and oxidation resistance. Recent studies show that $\mathrm{Nb}$ addition in alumina-forming alloys increases the $\mathrm{Cr}$ content in austenite, and may also reduce the oxygen solubility in the alloy matrix, which are favorable for external alumina scale formation [74-75]. There are also studies 
that have proved high Al concentrations (>50 at.\%) in Laves phase, which can explain the alumina scale covering the surface of Laves phase [76].

With regard to the microstructure stability during oxidation tests, AFA-1 alloys show the same phase composition as before exposure, namely B2-NiAl precipitates embedded in austenite matrix. However, the B2-NiAl phase underneath the oxide scale acting as Al-reservoir was consumed up to a depth of $6 \mu \mathrm{m}$ for the formation of alumina scale. AFA-2, AFA-3 and HEA-1 with single FCC solid solution maintain the structure stability during the oxidation test. HEA-2 shows the depletion of the inter-dendritic B2-NiAl phase underneath the oxide scale up to $20 \mu \mathrm{m}$, also due to formation of alumina scale. HEA-3 alloyed with $\mathrm{Nb}$ shows the microstructure stability during the oxidation test. HEA-4 with Ti addition also shows the stability of dendrite structure. However, the $\gamma^{\prime}-\mathrm{Ni}_{3}(\mathrm{Al}, \mathrm{Ti})$ inter-dendrite which acts as a reservoir of both $\mathrm{Ti}$ and $\mathrm{Al}$ show the depletion underneath the oxide scale.

\section{Conclusions}

The following conclusions can be given based on the experimental results:

(a) AFA-1(Fe-7Al-15Cr-27Ni) with $7 \mathrm{wt}$.\% Al addition has formed a duplex FCC plus B2-NiAl microstructure, and AFA-2 and AFA-3 with 3 wt.\% Al (Fe-3Al-16Cr-(19-21)Ni-0.5Y) have formed single FCC solid solution (austenite) after annealing at $1250{ }^{\circ} \mathrm{C}$ for $2 \mathrm{~h}$. The matrix of as-cast $\mathrm{HEA}-1$ ( $\left.\mathrm{Al}_{7.9} \mathrm{Cr}_{23.2} \mathrm{Ni}_{34.8} \mathrm{Fe}_{\text {bal }}\right)$ consists of single FCC solid solution, while HEA-2 ( $\left.\mathrm{Al}_{8.9} \mathrm{Cr}_{23.1} \mathrm{Ni}_{34.3} \mathrm{Fe}_{\text {bal }}\right)$ has formed FCC plus B2-NiAl phases. Adding $\mathrm{Nb}$ or Ti to Al-Cr-Ni-Fe HEA alloy backbone promotes the formation of Laves phase $\left(\mathrm{Fe}_{2} \mathrm{Nb}\right)$ and $\gamma^{\prime}-\mathrm{Ni}_{3}(\mathrm{Al}, \mathrm{Ti})$ into the $\mathrm{FCC}$ solid solution matrix, respectively.

(b) AFA model alloys with the composition Fe-3Al-16Cr-(19-21) Ni (wt.\%) have shown an excellent oxidation resistance to steam by forming external $\alpha-\mathrm{Al}_{2} \mathrm{O}_{3}$ scale at $1200^{\circ} \mathrm{C}$. With the yttrium addition, the scale adherence is improved and in consequence, the scale exfoliation phenomenon is avoided.

(c) HEAs with the formula $\mathrm{Al}_{(7.9-8.9)} \mathrm{Cr}_{(21.4-23.2)} \mathrm{Ni}_{(34.3-35)} \mathrm{Fe}_{\text {bal }}$ (at.\%) have formed $\alpha-\mathrm{Al}_{2} \mathrm{O}_{3}$ scale during exposure to steam at $1200^{\circ} \mathrm{C}$. By adding $\mathrm{Nb}$, the scale adherence has been improved in terms of reduced scale exfoliation compared to HEA alloys without $\mathrm{Nb}$. Adding Ti degrades the oxidation resistance of HEA alloy due to the formation of less protective $\mathrm{TiO}_{2}$ and $\mathrm{Fe}_{3} \mathrm{O}_{4}$ layers, leading to an extended $\mathrm{Al}$ internal oxidation.

(d) The type of oxide scale formed on alloy surface is determined by the oxygen partial pressure of metallic oxides and dissociation oxygen pressure of the steam. The formation of $\alpha-\mathrm{Al}_{2} \mathrm{O}_{3}$ scale prevents the oxidation of other alloying elements like $\mathrm{Cr}$, Fe, Ni due to its lowest oxygen partial pressure among the $\mathrm{Ti}-, \mathrm{Cr}-, \mathrm{Fe}-, \mathrm{Nb}-, \mathrm{Ni}-$ based oxides.

(e) The depletion of $\mathrm{B} 2-\mathrm{NiAl}$ and $\gamma^{\prime}-\mathrm{Ni}_{3}(\mathrm{Al}, \mathrm{Ti})$ phases observed in the region underneath the oxide scale confirms the role of these phases acting as Al reservoir for oxide scale formation. Moreover, $\gamma^{\prime}$ $\mathrm{Ni}_{3}(\mathrm{Al}, \mathrm{Ti})$ also serves as $\mathrm{Ti}$ reservoir which promotes the formation of $\mathrm{TiO}_{2}$.

(f) The model alloys from both systems (AFA and HEA) have similar corrosion behavior, forming protective alumina scales with comparable thickness (exception HEA with Ti), and show microstructural stability of the FCC matrix. 


\section{Data availability}

The raw/processed data required to reproduce these findings cannot be shared at this time due to technical or time limitations.

The datasets obtained during the current study are available from the corresponding author on reasonable request.

\section{Acknowledgment}

This work was supported by the Helmholtz program NUSAFE at the Karlsruhe Institute of Technology and partially funded by the EC Horizon 2020 project- IL TROVATORE (grant 740415). Hao Shi appreciates the PhD fellowship supported by the China Scholarship Council (CSC No. 201506230151).

\section{Reference}

[1] P. Nikolaidis, A. Poullikkas, A comparative overview of hydrogen production processes, Renew. Sust. Energ. Rev. 67 (2017) 597-611. https://doi.org/10.1016/j.rser.2016.09.044

[2] D.S. Gunarathne, P. Mellin, W. Yang, M. Pettersson, R. Ljunggren, Performance of an effectively integrated biomass multi-stage gasification system and a steel industry heat treatment furnace, Appl. Energ. 170 (2016) 353-361. https://doi.org/10.1016/j.apenergy.2016.03.003

[3] G. Bruni, C. Rizzello, A. Santucci, D. Alique, M. Incelli, S. Tosti, On the energy efficiency of hydrogen production processes via steam reforming using membrane reactors, Int. J. Hydrogen. Energy. 44 (2019) 988-999. https://doi.org/10.1016/i.ijhydene.2018.11.095

[4] P. Parthasarathy, K.S. Narayanan, Hydrogen production from steam gasification of biomass: influence of process parameters on hydrogen yield-a review, Renew. Energy. 66 (2014) 570-579. https://doi.org/10.1016/i.renene.2013.12.025

[5] Z. Liang, Y. Wang, Q. Zhao, Steam oxidation behavior of alloy 617 at $900{ }^{\circ} \mathrm{C}$ to $1100{ }^{\circ} \mathrm{C}$, METALL MATER TRANS A. 49 (2018) 3133-3144. https://doi.org/10.1007/s11661-018-4644-x

[6] I.G. Wright, R.B. Dooley, A review of the oxidation behavior of structural alloys in steam, International Materials Reviews 55 (2010) 129-167. https://doi.org/10.1179/095066010X12646898728165

[7] T. Dudziak, Steam Oxidation of Fe-Based Materials, High Temperature Corrosion 201615. http://dx.doi.org/10.5772/62935

[8] Z. Yu, M. Chen, C. Shen, S. Zhu, F. Wang, Oxidation of an austenitic stainless steel with or without alloyed aluminum in $\mathrm{O}_{2}+10 \% \mathrm{H}_{2} \mathrm{O}$ environment at $800{ }^{\circ} \mathrm{C}$, Corros. Sci. 121 (2017) 105-115. https://doi.org/10.1016/j.corsci.2017.03.015

[9] R.M.K.A. Krishnan, M.K. Asundi, Zirconium alloys in nuclear technology, Proceedings of the Indian Academy of Sciences Section C: Engineering Sciences 4 (1981) 41-56. https://doi.org/10.1007/BF02843474

[10] Z. Duan, H. Yang, Y. Satoh, K. Murakami, S. Kano, Z. Zhao, J.J. Shen, H. Abe, Current status of materials development of nuclear fuel cladding tubes for light water reactors, Nucl. Eng. Des. 316 (2017) 131150. https://doi.org/10.1016/i.nucengdes.2017.02.031

[11] C.R.D.F. Azevedo, Selection of fuel cladding material for nuclear fission reactors, Engineering Failure Analysis. 18 (2011) 1943-1962. https://doi.org/10.1016/j.engfailanal.2011.06.010

[12] M. Steinbrück, M. Große, L. Sepold, J. Stuckert, Synopsis and outcome of the QUENCH experimental program, NUCL ENG DES. 240 (2010) 1714-1727. https://doi.org/10.1016/j.nucengdes.2010.03.021 
[13] M. Steinbrück, N. Vér, M. Große, Oxidation of advanced zirconium cladding alloys in steam at temperatures in the range of $600-1200{ }^{\circ} \mathrm{C}$, Oxid. Met. 76 (2011) 215-232.

https://doi.org/10.1007/s11085-011-9249-3

[14] S.J. Zinkle, K.A. Terrani, J.C. Gehin, L.J. Ott, L.L. Snead, Accident tolerant fuels for LWRs: A perspective, J. Nucl. Mater. 448 (2014) 374-379. https://doi.org/10.1016/i.jnucmat.2013.12.005

[15] K.A. Terrani, S.J. Zinkle, L.L. Snead, Advanced oxidation-resistant iron-based alloys for LWR fuel cladding, J. Nucl. Mater. 448 (2014) 420-435. https://doi.org/10.1016/i.jnucmat.2013.06.041

[16] C.C. Tang, M. Steinbrueck, M. Stueber, M. Grosse, X. Yu, S. Ulrich, H.J. Seifert, Deposition, characterization and high-temperature steam oxidation behavior of single-phase $\mathrm{Ti}_{2} \mathrm{AlC}$-coated Zircaloy-4, Corros. Sci. 135 (2018) 87-98. https://doi.org/10.1016/i.corsci.2018.02.035

[17] B.A. Pint, K.A. Terrani, M.P. Brady, T. Cheng, J. R. Keiser, High temperature oxidation of fuel cladding candidate materials in steam-hydrogen environments, J. Nucl. Mater. 440 (2013) 420-427. https://doi.org/10.1016/j.jnucmat.2013.05.047

[18] J. Ehlers, D.J. Young, E.J. Smaardijk, A.K. Tyagi, H.J. Penkalla, L. Singheiser, W.J. Quadakkers, Enhanced oxidation of the $9 \% \mathrm{Cr}$ steel P91 in water vapour containing environments, Corros. Sci., 48 (2006) 3428-3454. https://doi.org/10.1016/j.corsci.2006.02.002

[19] Y. Yamamoto, M.P. Brady, Z.P. Lu, P.J. Maziasz, C.T. Liu, B.A. Pint, K.L. More, H.M. Meyer, E.A. Payzant, Creep-resistant, $\mathrm{Al}_{2} \mathrm{O}_{3}$-forming austenitic stainless steels, Science. 316 (2007) 433-436. DOI: 10.1126/science.1137711.

[20] B.A. Pint, K.A. Unocic, K.A. Terrani, Effect of steam on high temperature oxidation behavior of alumina-forming alloys, Mater. High. Temp. 32 (2015) 28-35.

https://doi.org/10.1179/0960340914Z.00000000058

[21] A. Jianu, R. Fetzer, A. Weisenburger, S. Doyle, M. Bruns, A. Heinzel, P. Hosemann, G. Mueller, Stability domain of alumina thermally grown on $\mathrm{Fe}-\mathrm{Cr}$-Al-based model alloys and modified surface layers exposed to oxygen-containing molten Pb, J. Nucl. Mater. 470 (2016) 68-75.

https://doi.org/10.1016/j.jnucmat.2015.12.009

[22] W. Ding, H. Shi, A. Jianu, Y. Xiu, A. Bonk, A. Weisenburger, T. Bauer, Molten chloride salts for next generation concentrated solar power plants: Mitigation strategies against corrosion of structural materials, Sol. Energy. Mater. Sol. Cells. 193 (2019) 298-313.

https://doi.org/10.1016/j.solmat.2018.12.020

[23] L.F. He, P. Roman, B. Leng, K. Sridharan, M. Anderson, T.R. Allen, Corrosion behavior of an alumina forming austenitic steel exposed to supercritical carbon dioxide, Corros. Sci. 82 (2014) 67-76. https://doi.org/10.1016/j.corsci.2013.12.023

[24] A.R.V. Put, K.A. Unocic, M.P. Brady, B.A. Pint, Performance of chromia-and alumina-forming Fe-and Ni-base alloys exposed to metal dusting environments: The effect of water vapor and temperature, Corros. Sci. 92 (2015) 58-68. https://doi.org/10.1016/i.corsci.2014.11.022

[25] C. Tang, A. Jianu, M. Steinbrueck, M. Grosse, A. Weisenburger, H.J. Seifert, Influence of composition and heating schedules on compatibility of FeCrAl alloys with high-temperature steam, J. Nucl. Mater. 511 (2018) 496-507. https://doi.org/10.1016/i.jnucmat.2018.09.026

[26] R.B. Rebak, V.K. Gupta, M. Larsen, Oxidation Characteristics of Two FeCrAl Alloys in Air and Steam from $800{ }^{\circ} \mathrm{C}$ to $1300{ }^{\circ} \mathrm{C}$, Jom 70 (2018) 1484-1492. https://doi.org/10.1007/s11837-018-2979-9

[27] K.A. Terrani, B.A. Pint, Y.J. Kim, K.A. Unocic, Y. Yang, C.M. Silva, H.M. Meyers, R.B. Rebak, Uniform corrosion of FeCrAl alloys in LWR coolant environments, J. Nucl. Mater. 479 (2016) 36-47. https://doi.org/10.1016/j.jnucmat.2016.06.047

[28] H.P. Qu, Y.P. Lang, C.F. Yao, H.T. Chen, C.Q. Yang, The effect of heat treatment on recrystallized microstructure, precipitation and ductility of hot-rolled Fe-Cr-Al-REM ferritic stainless steel sheets, Mater. Sci. Eng. A 562 (2013) 9-16. https://doi.org/10.1016/i.msea.2012.11.008 
[29] S. Kobayashi, T. Takasugi, Mapping of $475^{\circ} \mathrm{C}$ embrittlement in ferritic Fe-Cr-Al alloys, Scr. Mater. 63 (2010) 1104-1107. https://doi.org/10.1016/j.scriptamat.2010.08.015

[30] K.G. Field, Handbook on the Material Properties of FeCrAl Alloys for Nuclear Power Production Applications (FY18 Version: Revision 1) (No. ORNL/SPR-2018/905), 2018. Oak Ridge National Lab (ORNL), Oak Ridge, TN (United States). DOI: 10.2172/1474581

[31] Z. Sun, P.D. Edmondson, Y. Yamamoto, Effects of Laves phase particles on recovery and recrystallization behaviors of Nb-containing FeCrAl alloys, Acta. Mater. 144 (2018) 716-727. https://doi.org/10.1016/j.actamat.2017.11.027

[32] H. Kim, H. Jang, G.O. Subramanian, C. Kim, C. Jang, Development of alumina-forming duplex stainless steels as accident-tolerant fuel cladding materials for light water reactors, J. Nucl. Mater. 507 (2018) 1-14. https://doi.org/10.1016/j.jnucmat.2018.04.027

[33] M.P. Brady, Y. Yamamoto, M.L. Santella, P.J. Maziasz, B.A. Pint, C.T. Liu, Z.P. Lu, H. Bei, The development of alumina-forming austenitic stainless steels for high-temperature structural use, Jom 60 (2008) 12. https://doi.org/10.1007/s11837-008-0083-2

[34] M.P. Brady, Y. Yamamoto, M.L. Santella, L.R. Walker, Composition, microstructure, and water vapor effects on internal/external oxidation of alumina-forming austenitic stainless steels, Oxid. Met. 72 (2009) 311. https://doi.org/10.1007/s11085-009-9161-2

[35] Y. Yamamoto, M.P. Brady, M.L. Santella, H. Bei, P.J. Maziasz, B.A. Pint, Overview of strategies for hightemperature creep and oxidation resistance of alumina-forming austenitic stainless steels, Metall. Mater. Trans. A 42 (2011) 922-931. https://doi.org/10.1007/s11661-010-0295-2

[36] M.P. Brady, J. Magee, Y. Yamamoto, D. Helmick, L. Wang, Co-optimization of wrought aluminaforming austenitic stainless steel composition ranges for high-temperature creep and oxidation/corrosion resistance, Mater. Sci. Eng. A 590 (2014) 101-115. https://doi.org/10.1016/j.msea.2013.10.014

[37] Y. Yamamoto, G. Muralidharan, M.P. Brady, Development of L12-ordered $\mathrm{Ni}_{3}(\mathrm{Al}, \mathrm{Ti})$-strengthened alumina-forming austenitic stainless steel alloys, Scr. Mater. 69 (2013) 816-819. https://doi.org/10.1016/j.scriptamat.2013.09.005

[38] B. Hu, I. Baker, The effect of thermo-mechanical treatment on the high temperature tensile behavior of an alumina-forming austenitic steel, Mater. Sci. Eng. A 651 (2016) 795-804. https://doi.org/10.1016/j.msea.2015.11.036

[39] J.W. Yeh, S.K. Chen, S.J. Lin, J.Y. Gan, T.S. Chin, T.T. Shun, C.H. Tsau, S.Y. Chang, Nanostructured highentropy alloys with multiple principal elements: novel alloy design concepts and outcomes, Adv. Eng. Mater. 6 (2004) 299-303. https://doi.org/10.1002/adem.200300567

[40] X. Yang, Y. Zhang, Prediction of high-entropy stabilized solid-solution in multi-component alloys, Mater. Chem. Phys. 132 (2012) 233-238. https://doi.org/10.1016/i.matchemphys.2011.11.021

[41] B. Gwalani, V. Soni, M. Lee, S.A. Mantri, Y. Ren, R. Banerjee, Optimizing the coupled effects of HallPetch and precipitation strengthening in a Al0.3CoCrFeNi high entropy alloy, Mater. Des. 121 (2017) 254-260. https://doi.org/10.1016/i.matdes.2017.02.072

[42] D.B. Miracle, Critical assessment 14: High entropy alloys and their development as structural materials, Mater Sci Tech-Lond 31 (2015) 1142-1147. https://doi.org/10.1179/1743284714Y.0000000749

[43] S. Praveen, H.S. Kim, High-Entropy Alloys: Potential Candidates for High-Temperature ApplicationsAn Overview, Adv. Eng. Mater. 20 (2018) 1700645. https://doi.org/10.1002/adem.201700645

[44] T.K. Tsao, A.C. Yeh, C.M. Kuo, Murakami, H. High temperature oxidation and corrosion properties of high entropy superalloys, Entropy 18 (2016) 62. https://doi.org/10.3390/e18020062 
[45] T.M. Butler, J.P. Alfano, R.L. Martens, M.L. Weaver, High-temperature oxidation behavior of Al-CoCr-Ni-(Fe or Si) multicomponent high-entropy alloys, Jom 67 (2015) 246-259. https://doi.org/10.1007/s11837-014-1185-7

[46] H.M. Daoud, A.M. Manzoni, R. Völkl, N. Wanderka, U. Glatzel, Oxidation Behavior of Al8Co17Cr17Cu8Fe17Ni33, Al23Co15Cr23Cu8Fe15Ni15, and Al17Co17Cr17Cu17Fe17Ni17 Compositionally Complex Alloys (High-Entropy Alloys) at Elevated Temperatures in Air, Adv. Eng. Mater. 17 (2015) 1134-1141. https://doi.org/10.1002/adem.201500179

[47] X. Chen, Y. Sui, J. Qi, Y. He, F. Wei, Q. Meng, Z. Sun, Microstructure of Al1.3CrFeNi eutectic high entropy alloy and oxidation behavior at $1000^{\circ} \mathrm{C}$, J. Mater. Res. 32 (2017) 2109-2116.

DOI: https://doi.org/10.1557/jmr.2017.10

[48] H. Shi, A. Jianu, A. Weisenburger, C. Tang, A. Heinzel, R. Fetzer, F. Lang, R. Stieglitz, G. Müller, Corrosion resistance and microstructural stability of austenitic $\mathrm{Fe}-\mathrm{Cr}-\mathrm{Al}-\mathrm{Ni}$ model alloys exposed to oxygen-containing molten lead, J. Nucl. Mater. 524 (2019) 177-190.

https://doi.org/10.1016/j.jnucmat.2019.06.043

[49] H. Shi, Alumina forming alloys (steels, high entropy materials) for the mitigation of compatibility issues with liquid metals and steam in energy related, high-temperature applications, PhD thesis, Karlsruhe Institute of Technology (KIT), Karlsruhe, 2020. DOI: 10.5445/IR/1000105453 https://publikationen.bibliothek.kit.edu/1000105453 retrieved on 01.04.2020

[50] Y. Zhang, Y.J. Zhou, J.P. Lin, G.L. Chen, P.K. Liaw, Solid-solution phase formation rules for multicomponent alloys, Adv. Eng. Mater. 10 (2008) 534-538.

https://doi.org/10.1002/adem.200700240

[51] S. Guo, C.T. Liu, Phase stability in high entropy alloys: formation of solid-solution phase or amorphous phase, PROG. NAT. SCI-MATER. 21 (2011) 433-446.

https://doi.org/10.1016/S1002-0071(12)60080-X

[52] Z. Wang, S. Guo, C.T. Liu, Phase selection in high-entropy alloys: from non-equilibrium to quilibrium, Jom. 66 (2014) 1966-1972. https://doi.org/10.1007/s11837-014-0953-8

[53] US Nuclear Regulatory Commission, Acceptance criteria for emergency core cooling systems for lightwater nuclear power reactors, Code of Federal Regulations 10 (2010). https://www.nrc.gov/reading$\mathrm{rm} /$ doc-collections/cfr/part050/part050-0046.html retrieved on 01.04.2020

[54] M. Steinbrück, Oxidation of boron carbide at high temperatures, J. Nucl. Mater. 336 (2005) 185-193. https://doi.org/10.1016/i.jnucmat.2004.09.022

[55] D. Pan, R. Zhang, H. Wang, C. Lu, Y. Liu, Formation and stability of oxide layer in FeCrAl fuel cladding material under high-temperature steam, J. Alloys Compd. 684 (2016) 549-555. https://doi.org/10.1016/i.jallcom.2016.05.145

[56] K.A. Unocic, Y. Yamamoto, B.A. Pint, Effect of Al and Cr content on air and steam oxidation of FeCrAl alloys and commercial APMT alloy, Oxid. Met. 87 (2017) 431-441. https://doi.org/10.1007/s11085-017-9745-1

[57] J. Emo, Ph Maugis, A. Perlade, Austenite growth and stability in medium Mn, medium Al, Fe-C-Mn-Al steels, Comput. Mater. Sci. 125 (2016) 206-217. https://doi.org/10.1016/i.commatsci.2016.08.041

[58] C.C. Tang, M. Steinbrück, M. Große, T. Bergfeldt, H.J. Seifert, Oxidation behavior of Ti2AlC in the temperature range of $1400{ }^{\circ} \mathrm{C}-1600{ }^{\circ} \mathrm{C}$ in steam, J. Nucl. Mater. 490 (2017) 130-142. https://doi.org/10.1016/i.jnucmat.2017.03.016

[59] M. Fukumoto, H. Sonobe, M. Hara, H. Kaneko, Analysis of water vapor oxidation of Fe and Fe-Cr alloys by measuring the partial pressures of hydrogen and oxygen, Oxid. Met. 87 (2017), 405-416. https://doi.org/10.1016/j.jnucmat.2017.03.016 
[60] C.T. Fujii, R.A. Meussner, The Mechanism of the High-Temperature Oxidation of Iron-Chromium Alloys in Water Vapor, J. Electrochem. Soc. 111 (1964) 1215-1221. doi: 10.1149/1.2425963.

[61] R. Viswanathan, J. Sarver, J.M. Tanzosh, Boiler materials for ultra-supercritical coal power plantssteam side oxidation, J. Mater. Eng. Perform. 15 (2006) 255-274. https://doi.org/10.1361/105994906X108756

[62] HSC Chemistry 9, http://www.hsc-chemistry.net/v9 REACTION\%20EQUATIONS.html, retrieved on 09.12.2019.

[63] K.P.R. Reddy, J.L. Smialek, A.R. Cooper, ${ }^{18} \mathrm{O}$ Tracer studies of $\mathrm{Al}_{2} \mathrm{O}_{3}$ scale formation on NiCrAl alloys, Oxid. Met. 17 (1982), 429-449. https://doi.org/10.1007/BF00742122

[64] W.J. Quadakkers, H. Holzbrecher, K.G. Briefs, H. Beske, Differences in growth mechanisms of oxide scales formed on ODS and conventional wrought alloys, Oxid. Met. 32 (1989), 67-88. https://doi.org/10.1007/BF00665269

[65] B.A. Pint, J.A. Martin, L.W. Hobbs, ${ }^{18} \mathrm{O} / \mathrm{SIMS}$ characterization of the growth mechanism of doped and undoped $\alpha-\mathrm{Al}_{2} \mathrm{O}_{3}$, Oxid. Met. 39 (1993) 167-195. https://doi.org/10.1007/BF00665610

[66] F.A. Golightly, F.H. Stott, G.C. Wood, The influence of scale adhesion alloy yttrium additions on the oxide to an iron-chromium-aluminum oxidation of metals, Oxid. Met. 10 (1976) 163-186. https://doi.org/10.1007/BF00612158

[67] V.K. Tolpygo, D.R. Clarke, Competition between stress generation and relaxation during oxidation of an Fe-Cr-Al-Y alloy, Oxid. Met. 49 (1998) 187-212. https://doi.org/10.1023/A:1018828619028

[68] R.H. Bogaard, P.D. Desai, H.H. Li, C.Y. Ho, Thermophysical properties of stainless steels, Thermochim. Acta. 218 (1993) 373-393. https://doi.org/10.1016/0040-6031(93)80437-F

[69] S.L. Shang, H. Zhang, Y. Wang, Z.K. Liu, Temperature-dependent elastic stiffness constants of $\alpha$-and $\theta-\mathrm{Al}_{2} \mathrm{O}_{3}$ from first-principles calculations, J. Phys. Condens. Matter. 22 (2010) 375403. doi:10.1088/0953-8984/22/37/375403.

[70] K.L. Luthra, Stability of protective oxide films on Ti-base alloys, Oxid. Met. 36 (1991) 475-490. https://doi.org/10.1007/BF01151593

[71] A. Donchev, M. Schütze, Minimization of the Oxygen Embrittlement of Ti-Alloys. Theodor-HeussAllee, 25 60486, retrieved on 16.12.2019.

[72] R. Cueff, H. Buscail, E. Caudron, C. Issartel, F. Riffard, Oxidation of alumina formers at 1173 K: effect of yttrium ion implantation and yttrium alloying addition, Corros. Sci. 45 (2003) 1815-1831. https://doi.org/10.1016/S0010-938X(02)00254-8

[73] T. Amano, Y. Takezawa, A. Shiino, T. Shishido, Surface morphology of scale on FeCrAl (Pd, Pt, Y) alloys, J. Alloys. Compd. 452 (2008) 16-22. https://doi.org/10.1016/i.jallcom.2007.01.170

[74] M.P. Brady, Y. Yamamoto, M.L. Santella, B.A. Pint, Effects of minor alloy additions and oxidation temperature on protective alumina scale formation in creep-resistant austenitic stainless steels, Scr. Mater. 57 (2007) 1117-1120. https://doi.org/10.1016/i.scriptamat.2007.08.032

[75] Y. Yamamoto, M.P. Brady, M.L. Santella, H. Bei, P.J. Maziasz, B.A. Pint, Overview of strategies for hightemperature creep and oxidation resistance of alumina-forming austenitic stainless steels, Metall. Mater. Trans. A 42 (2011) 922-931. https://doi.org/10.1007/s11661-010-0295-2

[76] F. Stein, C. He, O. Prymak, S. Voß, I. Wossack, Phase equilibria in the Fe-Al-Nb system: Solidification behaviour, liquidus surface and isothermal sections, INTERMETALLICS 59 (2015) 43-58. https://doi.org/10.1016/i.intermet.2014.12.008

[77] Y. Yamamoto, M.P. Brady, G. Muralidharan, B.A. Pint, P.J. Maziasz, D. Shin, B. Shassere, S.S. Babu, C.-H. Kuo, Development of creep-resistant, alumina forming ferrous alloys for high-temperature structural use, Proceedings of the ASME 2018 Symposium on Elevated Temperature Application, of Materials for Fossil, Nuclear, and Petrochemical Industries, ETAM2018, 2018, https://doi.org/10.1115/ETAM2018-6727 ISBN: 978-0-7918-4076-4 
https://asmedigitalcollection.asme.org/PT/proceedings/ETAM2018/40764/V001T04A003/230452 retrieved on 01.04 .2020 